\title{
Cross-border Acquisitions by Chinese Enterprises: The Benefits and Disadvantages of Political Connections**
}

\section{Journal of Corporate Finance, Forthcoming}

\author{
Denis Schweizer*, Thomas Walker ${ }^{\dagger}$, and Aoran Zhang
}

\begin{abstract}
This paper explores whether and how political connections affect the likelihood of completing a cross-border M\&A deal for Chinese publicly listed, but privately-owned enterprises (POEs) and the resulting firm performance. In line with our proposed political connection trade-off theory, we find that POEs with politically connected top managers are more likely to complete a cross-border M\&A deal than POEs with no such connections, but that this comes at the cost of negative announcement returns and subsequent lower accounting performance. These findings support the idea that politically connected top managers engage in "political empire building" behavior at the cost of shareholders' wealth.
\end{abstract}

Keywords: China, Cross-border M\&As, Emerging Markets, Multinational Enterprises, Political Connections

JEL Classification: G15, G18, G34

* Concordia University, Associate Professor of Finance, John Molson School of Business, 1450 Rue Guy, Montreal, Quebec, Canada H3G 1M8, Phone: +1 514-848-2424, ext. 2926, Fax: +1-514-848-4500, e-mail: Denis.Schweizer@concordia.ca.

$\dagger$ Concordia University, Professor of Finance, John Molson School of Business, 1450 Rue Guy, Montreal, Quebec, Canada H3G 1M8, Phone: +1 514-848-2424, ext. 2387, Fax: +1-514-848-4500, e-mail: Thomas.Walker@concordia.ca.

* Concordia University, PhD Candidate in Finance, John Molson School of Business, 1450 Rue Guy, Montreal, Quebec, Canada H3G 1M8, e-mail: Aoran.Zhang@concordia.ca.

** Acknowledgments: We are grateful to the editors Greg Bell, Igor Filatotchev, Jeffry Netter, Annette Poulsen and an anonymous referee for many excellent comments and suggestions. We thank Gabriel Benito, Douglas Cumming, Sinziana Dorobantu, Benjamin Hammer, Wenxuan Hou, Ugur Lel, Juliane Proelss, and Zhenyu Wu as well as the participants of the Corporate Governance of a Multinational Enterprise: Firm, Industry and Institutional Perspectives conference (Atlanta, USA) for helpful comments. We also thank Max Cote for excellent research assistance. This research was funded by Concordia's Office of the Vice President, Research \& Graduate Studies (OVPRGS under grant number VS0192. Denis Schweizer gratefully acknowledges the financial support provided through the Manulife Professorship. A previous version of the paper was titled "Do Political Connections Help Privately Owned Chinese Enterprises Go Global?" 


\section{Introduction}

Outbound foreign direct investments (FDI) by multinational corporations play a vital role in the world economy. According to the 2016 World Investment Report (UNCTAD, 2016), a strong FDI rally occurred in 2015. Global FDI increased by $38 \%$ to $\$ 1.8$ trillion, a record high since the 2008 financial crisis. The surge in cross-border mergers and acquisitions (CBMA) is the principal contributor to the recovery of FDI. The value of cross-border deals soared to $\$ 721$ billion in 2015, almost double the amount in 2014 (\$432 billion).

After the Chinese Communist Party (CCP) launched its "go global" initiative in 2001, Chinese state-owned enterprises (SOEs) became increasingly active in the world. In fact, the outbound FDI of Chinese SOEs increased more than threefold between 2009 and 2015 to $\$ 128$ billion. This helped China become the world's third largest foreign investor after the U.S. and Japan. Moreover, China is the only developing economy among the top ten foreign investors. In contrast to other major developing economies whose outbound FDIs typically take the form of reinvested earnings, China’s FDI mainly consists of new equity investments (UNCTAD, 2016).

In 2006, the Chinese government also incorporated privately owned enterprises (POEs) in its go global strategy by starting to offer tax rebates and access to long-term financing at favorable terms to POEs (Cheng and Ma, 2010). Despite these efforts, however, there is (anecdotal) evidence that POEs continue to face severe limitations when conducting overseas investments today.

According to Cheng and Ma (2010), the Chinese government may have technically lifted many of the restrictions for POEs, but adequate assistance remains out of reach for several reasons. Some POEs find the approval procedure for going global to be tedious and overly time-consuming. To address this problem, Cheng and Ma suggest that a "one-stop-shop" approach to obtaining 
approvals would be more efficient. In addition, many POEs feel that they are at a serious disadvantage when attempting to obtain credit for international business transactions because the quotas for long-term loans are allocated exclusively to SOEs (Poncet, Steingress, and Vandenbussche, 2010; Guariglia, Liu, and Song, 2011). ${ }^{1}$ Furthermore, most of the major Chinese commercial banks are owned and controlled by the Chinese government and their primary function is to support SOEs' economic activities (Morck, Yeung, and Zhao, 2008). These banks tend to screen out POEs from their lending activities because they are considered high risk. Consequently, many Chinese POEs must turn to other sources, from employing their own capital (Liu and Tan, 2004) to raising capital overseas (Sutherland and Ning, 2011), or even allying with private equity (Financial Times, 2012).

Despite the ongoing restrictions faced by Chinese POEs, they have been challenging the dominance of SOEs in the area of cross-border acquisitions in recent years. As China Daily (2016) reports, in September 2016, China's privately-owned enterprises (POEs) overtook SOEs for the first time in outbound FDI. Specifically, POEs now lead in terms of both value and number of cross-border M\&A transactions, accounting for $65.3 \%$ of all deals. This development seems puzzling, given that the Chinese government has traditionally favoured SOEs for which it could effectively exercise its control rights. This raises the following question: Why have the cross-border investments of SOEs slowed down and how did POEs come to replace SOEs as the leaders of Chinese cross-border deals?

Some recent examples of SOEs experiencing setbacks in the global M\&A market illustrate the

\footnotetext{
${ }^{1}$ There are three policy banks in China coordinating government-directed spending: The Agricultural Development Bank of China, the China Development Bank, and the Export-Import Bank of China. They were established in 1994 and are responsible for financing economic and trade development as well as state-controlled projects.
} 
potential reasons for the recent dominance of Chinese POEs in cross-border acquisitions. First, Tsinghua Unigroup, an SOE, attempted to acquire West Digital Corporation (a data storage group in the U.S.) in 2015. However, Tsinghua withdrew the $\$ 3.8$ billion offer after the deal was flagged for investigation by the Committee on Foreign Investment in the United States (CFIUS) (see Financial Times, 2016). Similarly, the CFIUS challenged Philips' attempt to sell its lighting business to a Chinese consortium. Similar interventions have also occurred in other countries. In Germany, for example, the Federal Ministry of Economics and Energy withdrew its clearance certificate for the takeover of Aixtron, a semiconductor producer, by Fujian Grand Chip Investment Group (a Chinese state-owned bidder), indicating Berlin's reluctance to transfer Aixtron's cuttingedge technology and revealing security-related technologies through the acquisition (see New York Times, 2016). President Obama even issued an executive order prohibiting the acquisition of Aixtron's U.S.-based business. Presumably in response to the previously described case, as well as similar cases that took place around the same time in Germany, the German government initiated a regulation review at the EU-level for takeovers by investors from outside the EU and proposed the following changes: a) doubling the time for reviewing takeovers, b) restricting indirect takeovers, and c) re-defining a "threat to public order" to include a diverse array of new sectors that are considered critical (see The Telegraph, 2017).

These events clearly suggest increasing headwinds for Chinese SEOs that wish to complete cross-border acquisitions, as foreign governments fear the indirect transfer of cutting-edge technology or the loss of ownership of businesses with national security or strategic importance to Chinese government-controlled firms. Similar trends are identified by Linklaters (2017) who notes that in 2016, up to one-third of Chinese outbound M\&A deals were blocked by the host 
governments - the vast majority of these deals involving Chinese SOEs. For POEs, ties to the Chinese government are less direct and support is offered in the form of tax rebates as well as subsidies and favorable financing terms if the firm completes the cross-border acquisition. This is neatly summarized by a member of the Chinese People's Political Consultative Conference (CPPCC) who suggests that "Given the fact that SOEs often experience setbacks when acquiring foreign companies in advanced economies, POEs are encouraged to acquire the high technology for the growth of China's economy. Because POEs rarely have Chinese government background, they can avoid the scrutiny from foreign governments targeting Chinese SOEs. The government should provide financing to POEs for their cross-border deals and even state-owned companies could provide funding in the background to POEs" (see Sina Finance, 2010).

The above analysis suggests that using politically (well-) connected POEs as government agents appears to be the best solution because politically connected top managers tend to actively respond to the government's suggestion to proceed with cross-border acquisitions and are better equipped to overcome market discrimination against POEs with regard to, for example, securing sufficient long-term financing from state-owned commercial banks (see Li et al., 2008). However, the fact that politically connected POEs have the incentives and means to carry out cross-border acquisitions does not necessarily imply that these acquisitions constitute sound business practice nor that they will be financially successful. This somewhat contradictory state of affairs is a key theme of the current paper and is illustrated by the following examples. The Anbang Insurance Group, a Chinese POE whose CEO and chairman has working experience in a governmental department (the Administration for Industry and Commerce), was aggressively bidding for Starwood. This raised concerns that the acquisition was motivated not entirely by commercial 
interests, but also by political ones, including the desire to acquire technology and expertise in strategic sectors (see Bloomberg, 2016). Similarly, in mid-2017, Hytera Communications, a Chinese POE telecom giant, successfully acquired Norsat, a Vancouver-based Canadian satellite communications company, thereby gaining access to "sensitive Western satellite technology." This deal was heavily criticized because of the chairman's close ties to the Chinese Ministry of Public Security, which oversees China's security agencies. In response to the acquisition, the U.S Defense Department initiated a review of all existing contracts with Norsat because the same satellite communications technology would presumably now also be used by the Chinese (see The Globe and Mail, 2017). These examples suggest that one of the primary motivations for cross-border acquisitions by Chinese POEs is strategic asset seeking (see Deng, 2009; Huang and Chi, 2014).

Further evidence of the fact that cross-border acquisitions completed by politically connected POEs may not be motivated purely by commercial interests comes from a report by the Ministry of Commerce of China, which revealed that only $13 \%$ of the cross-border deals made by Chinese companies are profitable (see Sina Finance, 2016). As mentioned above, a possible explanation is that politically connected top management of POEs aims to acquire strategic assets largely for political motives, trying to complete the acquisition at all costs and thereby sometimes overpaying. This behaviour was clearly evident in the previously described case of Anbang Insurance Group which started a bidding competition for Starwood and ended up in a high-risk financial model (see Bloomberg, 2016). According to analysts, Landbridge Group, a Chinese privately-owned company, recently bought the Australian port of Darwin for more than twice its true value (see $A B C, 2015$ ). Another example of politically connected top management attempting to "flatter" the government by blindly following its recommendations is the recent trend for Chinese firms to buy foreign 
football clubs. They rush into these deals not because they are particularly good investments, but because President Xi Jinping has expressed hopes that China will become a soccer powerhouse (see South China Morning Post, 2017).

A further possible explanation for the failure of outbound investments is that after deal completion, Chinese POEs often find that competition in the host country is much tougher and that some business practices commonly accepted in China, such as relaxing health and safety standards, cannot be mirrored abroad (see Bloomberg, 2017). A similar argument was also invoked by Antkiewicz and Whalley (2006) in discussing why most of the cross-border M\&A transactions attempted by Chinese SOEs are unsuccessful in Organization of Economic Cooperation and Development (OECD) countries.

We use the term political connection trade-off theory to refer to the oppositional situation whereby politically connected POEs are better positioned (than their unconnected counterparts) to manage the necessary logistics of a cross-border M\&A, but the deals often come at the cost of poor financial performance. If productivity and profitability were frequently to matter less than political goals, politically connected POEs would subject themselves to moral hazard and create a “principal-principal” conflict between the state and the firm's shareholders (see Young et al., 2008) Specifically, the "political empire building" behavior of politically connected top managers would have a negative effect on shareholders' wealth.

To test the political connection trade-off theory, i.e. that politically connected top managers of POEs are more likely to complete a cross-border M\&A transaction than their unconnected

\footnotetext{
2 The hypothesized principal-principal problem conflict leans on the well documented principal-agent problem. For Chinese POEs with politically connected managers, it describes the behavior of politically active managers who pursue state interests and their own political careers at the detriment of the firm's shareholders.
} 
counterparts, but at the cost of poorer performance, we conduct several analyses. First, based on a sample of 1,782 Chinese POEs listed on either the Shanghai or Shenzhen Stock Exchanges, we analyze the POEs' likelihood of completing a cross-border M\&A deal. Consistent with our argumentation, we find that politically connected POEs have a greater likelihood of successfully completing a cross-border merger or acquisition than their unconnected counterparts. Our results remain robust after invoking a variety of robustness checks.

In a second set of analyses, we examine stock price returns and the return on equity after the announcement of a cross-border M\&A to test for the market reaction and the impact on firm performance. We expect both the short- and long-term post-M\&A performance to be lower for politically connected POEs than for non-politically connected POEs. We show that this is indeed the case; POEs with a politically connected chairman or CEO show significantly lower announcement returns (to the tune of about 1.5 to 2 percent) and are less profitable than their nonconnected counterparts within the first three years after deal completion.

Overall, our study supports the political connection trade-off theory and makes the following contributions to the existing literature. First, to the best of our knowledge, this study is the first to deliver a theoretical framework and empirical analysis of how political connections influence a Chinese POE's decision to engage in cross-border M\&A activities and what the related costs of these connections are. Second, our study contributes to the literature on how governmental influence in emerging markets can affect the decisions of domestic firms to expand internationally through cross-border M\&A deals (see Xiao and Sun, 2005; Rui and Yip, 2008; Peng, Wang, and Jiang, 2008; Luo, Xue, and Han, 2010; and Du and Boateng, 2015). Finally, our study contributes to the research methodology typically used in studies in this area. 
The remainder of this study proceeds as follows. Section 2 develops our hypotheses, while Section 3 describes the data collection process. Our research methodology is presented in Section 4 and Section 5 provides our empirical results. Section 6 concludes.

\section{Hypothesis Development}

\subsection{Political Connections and Cross-border M\&A Deals}

Political connections can be valuable to firms' financing activities in both developed and developing countries, as many empirical studies have shown. ${ }^{3}$ However, the benefits are generally more pronounced in emerging markets because of their relatively inferior institutional environments, more concentrated ownership structures, and less efficient legal systems (La Porta et al., 1998, 2000). In the case of China, we argue that the political connections of top management team members are more beneficial for POEs than SOEs simply because Chinese POEs face a different institutional environment. SOEs in China are the pillars of the national economy, while POEs must seek ways to overcome the discrimination they face in the capital market. One method is to build political ties with the government by hiring top managers with specific political backgrounds (Chen et al., 2011). Positive influences of political connections on various economic activities of Chinese POEs are documented in many empirical studies. Li et al. (2008) find that POE founders are more likely to obtain financing from state-controlled institutions if they have political party membership. Politically connected Chinese firms are also more likely to obtain loans with longer terms and lower interest rates when borrowing from state-owned banks (see Luo and Zhen, 2008; Yu and Pan, 2008; and Yuan, Jing, and Liao, 2010). Luo and Liu (2009) note that it is

\footnotetext{
${ }^{3}$ See, for example, Roberts (1990), Fisman (2001), Khwaja and Mian (2005), Adhikari, Derashid, and Zhang (2006), Charumilind, Kali, and Wiwattanakantang (2006), Faccio (2006), Claessens, Feijen, and Laeven (2008), Bunkanwanicha and Wiwattanakantang (2009), and Schweizer, Walker, and Zhang (2016).
} 
easier for politically connected POEs in China to enter industries with high entry barriers, such as banking and telecommunications. Similarly, Li and Zhou (2015) find that politically connected POEs are more likely to get IPO requests approved and that such POEs are less likely to be subjected to on-site auditing from regulatory authorities.

Based on the arguments above, we expect that POEs whose top managers have political ties to the Chinese government are both more willing and more able to complete cross-border M\&A transactions. Thus, we postulate Hypothesis 1 as follows:

\section{Hypothesis 1: Politically connected POEs are more likely to complete cross-border M\&A deals than unconnected POEs.}

\subsection{Corporate Governance and Cross-border M\&A Deals}

In the previous subsection, our argument for the value of political connections is based on the institutional environment of a POE's home country. Nevertheless, when POEs enter the global market, they are also affected by the institutional environment of the host countries (see Kostova, 1999; Lu et al., 2014; and Regner and Edman, 2014). Meyer and Rowan (1977) argue that when companies enter a foreign market, they are likely to adapt to the prevalent organizational practices and structures in the host country with the goal of enhancing their overall sense of legitimacy.

This issue is more prominent when companies from emerging economies, with relatively poorer institutional environments, enter more advanced economies that typically feature higher-level institutional environments (as is mostly the case in the present study). Therefore, we expect that some Chinese POEs will endeavor to ameliorate their corporate governance to ensure that they meet local governance standards before attempting to conduct cross-border deals. This would give 
them a greater chance of being successful. Therefore, in Hypothesis 2, we posit the following relationship between corporate governance and POEs' cross-border deals:

Hypothesis 2: POEs with better corporate governance are more likely to complete a crossborder $M \& A$ deal.

\subsection{The Performance of Acquiring POEs}

It is commonly known that the Chinese government intervenes with SOEs' business activities by appointing managers that have strong political ties. These politically connected managers can assist the government in achieving political and social objectives, which may be prioritized over commercial goals (see $\mathrm{Wu}, \mathrm{Wu}$ and Rui, 2012). By following the government's recommendations, the managers can increase their political capital, which is vital to their political career. However, decision making based on a manager's political agenda may come at the expense of shareholders' wealth, creating a principal-principal conflict between the intervening government and non-state shareholders (see Young et al., 2008). This conjecture is supported by empirical analysis. For example, Wu, Wu, and Rui (2012) show that SOEs with politically connected top managers have lower accounting performance (measured by ROA) and fewer growth options (measured by Tobin's q). Similarly, Fan et al. (2007) examine the performance of Chinese IPO firms using a sample of 790 partially privatized SOEs. Their empirical analysis shows that IPO firms whose CEO is politically connected to the Chinese government have lower initial returns and lower accounting performance in the three years after going public. They argue that the political rent seeking behavior of politically connected CEOs expropriates the wealth of minority shareholders, which in turn harms firm performance. Evidence of the principal-principal conflict is also found by Sun, 
Vinig, and Hosman (2017) who show that SOEs have significantly lower stock performance around outbound M\&A announcements than POEs, for which political connections are arguably less present. They reason that although SOEs enjoy patronage in obtaining bank loans with a lower cost of borrowing to finance their cross-border deals, this advantage is often misused in the sense that SOEs are more likely to invest in risky cross-border deals or to overpay for the target.

Although the above evidence pertains to SOEs, we conjecture that if politically connected POEs are politically motivated to conduct cross-border M\&A transactions (e.g. for political empire building), then instead of maximizing shareholder wealth, a similar principal-principal conflict may occur, resulting in adverse firm performance. In contrast, non-connected POEs, being unaffected by this conflict, are more likely to pursue a cross-border M\&A for commercial reasons, which is in line with shareholder interests. Based on these arguments, we formulate Hypothesis 3 as follows:

Hypothesis 3: Acquiring POEs with political connections have lower stock returns around the time of a cross-border $M \& A$ announcement and lower post-merger financial performance than non-politically connected POEs.

\section{Data}

\subsection{Financial and Corporate Governance Data}

We identify listed Chinese POEs by using the China Listed Private Enterprise Research Database, provided by China Stock Market and Accounting Research (CSMAR), which includes all Chinese POEs listed on the Shanghai or Shenzhen Stock Exchanges. In contrast to Chinese SOEs, POEs are defined as enterprises directly controlled by individuals, families, other non-state entities, or foreign enterprises. Financial data for the Chinese POEs in our sample comes from CSMAR's China Stock Market Financial Statement Database and the corporate governance data 
comes from CSMAR's China Listed Firms' Corporate Governance Research Database. We found that some POEs are missing information on corporate governance-related data. We therefore manually collect the missing data from the Stockstar website (www.stockstar.com), which provides detailed information about the top management of firms traded on both exchanges. Our sample begins in 2007 after the Chinese government issued a call for stronger financing support for POEs wishing to go global and ends in 2016 . We winsorize all the financial data at the $1 \%$ and $99 \%$ levels to minimize the influence of potential outliers. Our final sample consists of 1,782 POEs and 9,946 firm-year observations.

\subsection{Identification of Cross-border M\&A Transactions by Chinese POEs}

We define a POE as acquisitive if a cross-border M\&A deal was completed during the observation period. We obtain the cross-border deals of Chinese POEs from CSMAR's China Listed Firms' Merger \& Acquisition, Asset Restructuring Research Database. We exclude any cases where the cross-border M\&A occurred in tax havens or offshore financial centers because firms acquired in this way are not "real" or "producing" foreign companies, but rather Chinese "shell companies."

We find that 290 Chinese POEs completed 385 cross-border M\&A deals between 2007 to 2016. We exclude two POEs that engaged in cross-border M\&A activities before that time period, because these acquisitions might follow a different rationale. We consider the remaining 288 firms completing 385 cross-border M\&A transactions as acquiring POEs (see Table 1). CSMAR's China Listed Firms' Merger \& Acquisition, Asset Restructuring Research Database also provides the

\footnotetext{
${ }^{4}$ Our sample excludes the following tax havens and offshore financial centers: American Samoa, the Bahamas, Bermuda, the British Virgin Islands, the Cayman Islands, Mauritius, Panama, and Samoa.
} 
country of origin of each overseas target that is acquired. In total, the cross-border deals completed

by Chinese POEs span forty countries (see Table 2 for an overview).

\subsection{Identification of Political Connections}

We proxy for political connections by following the recent literature by Faccio (2006), Fan, Wong, and Zhang (2007), Li and Zhou (2015), and Schweizer, Walker, and Zhang (2016). The present study only considers the political background of the Chinese POE's board chairman and CEO. We hand-collect the information for each company in our sample from Stockstar, which provides detailed past and current work experience for the top management of each listed company.

We define a POE's chairman or CEO as politically connected if he or she is or was a representative in the People's Congress (PC), the Chinese People's Political Consultative Conference (CPPCC), an officer in local or central government, or an officer in the military. We code the political connection dummy variable (Connection) as 1 for each year since the chairman or CEO is politically connected, and 0 otherwise (see Li and Zhou, 2015; Schweizer, Walker, and Zhang, 2016). In addition, we measure the strength of the political connections of each firm's chairman or CEO by creating a political connection index (PC Index). The value of this index ranges from 1 to 3 depending on the strength of the political ties (where 3 represents the strongest political connection). ${ }^{5}$

\footnotetext{
${ }^{5}$ According to a research report by Harvard University's Kennedy School, the PC, in conjunction with the CPPCC, act as the legislative arm of the government and thus as the highest political entity in China (see Saich, 2015). The PC's functions include: overseeing the work of government departments and electing major officials; amending the constitution; supervising the enforcement of constitutional and legal enactments; and examining and approving the state budget and the economic plan. Members serving on the standing committee of the PC and CPPCC command particular power, as they work actively on law-making. In addition, Saich (2015) notes that the PC and CPPCC play more than a ceremonial role in China. Therefore, we assign the highest PC Index value of 3 to POEs in which the top managers are (or were) members of the standing committee of the PC and CPPCC, as well as to POEs whose top manager is the head of the central or provincial government. If the top managers of a POE are ordinary members of the PC or CPPCC, we assign a value of 2 to the PC Index. Finally, if the chairman or CEO is only an officer of a specific governmental department, or was an officer in the army, his or her political connections are considered more limited; hence, we assign a value of 1 to the PC Index.
} 


\subsection{Measuring Corporate Governance}

To examine the impact of corporate governance on Chinese POEs becoming acquisitive overseas, we construct a comprehensive index that measures the overall corporate governance level of Chinese POEs. Our index aims to reflect a company's overall governance quality more accurately than single governance factors. It also eliminates multicollinearity that may arise in multivariate regressions when using single governance factors (Brown, Beekes, and Verhoeven, 2011). The advantages of a corporate governance index have been elaborated upon quite extensively in the extant literature (see Gompers, Ishii, and Metrick, 2003; Brown and Caylor, 2006; Dutordoir, Strong, and Ziegan, 2014; and Shan, 2015).

We follow Shan (2015) and construct an equally weighted corporate governance index for Chinese listed firms according to China's two-tier board system, but modify where necessary to account for the fact that our sample includes only POEs and no SOEs. Thus, we exclude the factor differentiating SOEs and POEs. We also exclude a factor for cross-listings. ${ }^{6}$ We obtain the corporate governance data from CSMAR's China Listed Firms' Corporate Governance Research Database and construct the final index (Gov Index) using nine equally weighted corporate governance factors. Detailed information on the construction of the index is provided in Panel B of Table A1 in the appendix.

\footnotetext{
${ }^{6}$ In our sample, four POEs are cross-listed on the Hong Kong Stock Exchange. Because Hong Kong is a self-governing special administrative region of the People's Republic of China, those four POEs cannot be considered real cross-listed firms. We also checked whether these POEs completed cross-border deals within our sample period and they did not.
} 


\subsection{Measuring Financial Performance}

To examine how cross-border M\&A deals affect a POE's performance, we calculate short-term stock returns in response to the announcement of a cross-border M\&A deal. We collect all stock returns for acquiring POEs and the value-weighted Shanghai and Shenzhen Composite Index from CSMAR's China Stock Market Trading Database. To examine the accounting based performance of acquiring POEs, we measure each firm's return on equity $(R O E)$ three years after deal completion.

\subsection{Control Variables}

We include an array of control variables that could potentially affect the likelihood of a Chinese POE carrying out a cross-border deal: profitability (ROA), leverage (Leverage), firm size (Firm Size), growth opportunities (Tobin's q), and a tangible asset ratio (Tangibility). We also use those variables to conduct a propensity score matching (PSM) technique. Detailed information for the control variables is provided in Panel A of Table A1 in the appendix.

To study the market reaction to the cross-border announcement, we include the following deal characteristics: the cultural difference between China and the country in which the target firm is located (Hofstede and Culture Distance), a frequent acquirer dummy (Multi Acquirer), deal value (Deal Size), a public listed target dummy (Public Target), method of payment dummies (All Cash Deal and All Stock Deal), and a legal origin dummy (Common Law). We obtain deal specific characteristics from CSMAR's Merger \& Acquisition, Asset Restructuring Research Database. 


\section{Methodology}

\subsection{Political Connections and Cross-border M\&A}

To examine how political connections can affect the likelihood of becoming an acquisitive POE, we carry out the following panel logit regressions which take account of the fact that some acquisitive POEs complete more than one cross-border M\&A deal:

$$
\begin{gathered}
{\operatorname{CBMA}(1 / 0)_{i, t}=}=\alpha+\beta_{1} \cdot \text { Political Connections }_{i, t}+\beta_{2} \cdot \text { Gov Index }_{i, t}+\boldsymbol{v}_{\boldsymbol{n}} \cdot \boldsymbol{N}_{\boldsymbol{i}, \boldsymbol{n}, \boldsymbol{t}}+ \\
\varphi_{k}+\pi_{t}+\varepsilon_{i, t}
\end{gathered}
$$

where $C B M A$ is a binary variable that equals 1 if Chinese POE i completes a cross-border deal in year t, and 0 otherwise; Political Connections are measured by either the independent variable Connection or PC Index; Gov Index captures the potential influence of overall corporate governance quality on the likelihood of completing a cross-border deal; $\mathbf{N}_{\boldsymbol{n}}$ is a vector of firmspecific characteristics (ROA, Leverage, Firm Size, Tobin's $q$, Tangibility); $\varphi_{k}$ are industry fixed effects $^{7}$; and $\pi_{t}$ are year fixed effects. If political connections increase a Chinese POE's likelihood of acquiring overseas targets, we expect the coefficients on Connection or the PC Index $\left(\beta_{1}\right)$ to be positive. Similarly, if Chinese POEs with better corporate governance have a greater chance of entering the global market, we expect the coefficient on the Gov Index $\left(\beta_{2}\right)$ to be positive.

We next describe the robustness checks pertinent to this part of the study (i.e. the effect of political connections). Firstly, we describe the steps taken to address any concerns about a selfselection bias, i.e. that politically connected top managers may not be randomly distributed across POEs. For example, larger and more profitable POEs may be more capable of building political connections by hiring a chairman or $\mathrm{CEO}$ with a political background. To overcome such a bias,

\footnotetext{
${ }^{7}$ We use fifteen industry dummy variables based on CSMAR's industry classifications.
} 
we use the propensity score matching (PSM) technique to study the pure effect of political connections on cross-border M\&A activity. The treatment variable is cross-border M\&A $(C B M A)$. We use the nearest neighbor matching method to match acquiring firms in the year before completing a cross-border M\&A with non-acquiring POEs on the vector of control variables $(R O A$, Leverage, Firm Size, Tobin's q, Tangibility). This results in two subsamples: 1) 770 (= 385 acquiring plus 385 control) firm-years when considering all cross-border M\&A deals and 2) 576 (= 288 acquiring plus 288 control) firm-years when only considering deals which were the first cross-border M\&A transactions carried out by the POE in question. For each subsample, we re-run equation (1), but instead of a panel regression we use a cross sectional logistic regression.

A further robustness check is carried out to examine whether political connections identified via a firm's ownership structure (i.e. the presence of politically connected blockholders ${ }^{8}$ ) influence a POE's decision to engage in cross-border M\&A activities. To measure the blockholder effect we create two additional variables: the ownership percentage of the largest politically connected blockholder (LBH Connection) and a dummy variable that is set equal to 1 if more than one blockholder is politically connected and 0 otherwise (Multi BH Connections). We consider a blockholder to be politically connected if he or she has political ties to the government (as in the definition of political connections for top managers) or if the blockholder is the state. We obtain information about blockholders' backgrounds from the Stockstar website. To isolate the effect of ownership-level political connections from management-level political connections, we only include politically-connected blockholders who are not top managers at the same time.

\footnotetext{
${ }^{8}$ A blockholder holds at least $10 \%$ of the voting rights (see, Thomsen, Pedersen, and Kvist, 2006).
} 
A third robustness check determines whether the results are primarily driven by "active" acquisitive POEs, i.e. POEs that complete more than one acquisition during our sample period. To this end, we employ both panel Poisson regressions and post-matching cross-sectional Poisson regressions (and using the same PSM technique as in the logit model). The baseline model follows the logic of equation (1), but the dependent variable is now a count variable that measures the number of overseas targets acquired by a POE over our sample period:

$$
\begin{aligned}
\operatorname{Count}(C B M A)_{i, t}= & \alpha+\beta_{1} \cdot \text { Political Connections }_{i, t}+\beta_{2} \cdot \text { Gov Index }_{i, t}+\boldsymbol{v}_{\boldsymbol{n}} \cdot \boldsymbol{N}_{\boldsymbol{i}, \boldsymbol{n}, \boldsymbol{t}}+ \\
& +\varphi_{k}+\pi_{t}+\varepsilon_{i, t}
\end{aligned}
$$

\subsection{Endogeneity Concerns}

We note that the potentially endogenous nature of political connections may impede the robustness of the proposed causal relationship between political connections and the likelihood of acquiring overseas targets for Chinese POEs. We conduct a quasi-natural experiment to cope with this problem. Specifically, we examine whether chairman/CEO turnovers that result in an increase in the PC Index (i.e. that cause firms to be more politically connected) increase the likelihood of POEs engaging in cross-border M\&A transactions. Our first step is to apply a similar PSM routine to that used in our previous analysis. We include the $P C$ Index as an additional matching variable and match in the year before the POE completed its first cross-border M\&A deal (288 firm-year observations) with POEs that did not acquire any overseas companies during the observation period. This ensures that acquiring and non-acquiring POEs have "identical" company characteristics just before their first cross-border M\&A. If political connections facilitate cross-border deal completions, we expect that companies replacing their top management with more politically connected successors will be more likely to engage in cross-border M\&A activities. 
To measure this effect, we create a dummy variable (Political Turnover) that equals 1 if the CEO or chairman is replaced in the five years before the firm completed the first cross-border M\&A deal with a $\mathrm{CEO} /$ chairman with a higher $P C$ Index (stronger political ties), and 0 if there is no turnover or a turnover that does not result in a higher PC Index. ${ }^{9}$ Our model reads as follows:

$$
\begin{gathered}
\operatorname{CBMA}_{(1 / 0)_{i, t}}=\alpha+\beta_{1} \cdot \text { Political Turnover }_{i, t}+\beta_{2} \cdot \text { Connection }_{i, t-1}+\beta_{3} \cdot \\
\text { Gov Index } \\
t-1
\end{gathered}
$$

The variable of interest in equation (3) is the coefficient on Political Turnover $\left(\beta_{1}\right)$. If political connections indeed increase the likelihood of a Chinese POE going global, we expect $\beta_{1}$ to be positive. We also perform a robustness check in which we replace Political Turnover with a variable that indicates the change in the political connections of the blockholders within the five years before the firm's first cross-border M\&A (PBH Turnover).

\subsection{The Financial Performance of Chinese POEs after Cross-border M\&A Announcements}

We begin our analysis of how the market reacts to cross-border M\&A announcements by Chinese POEs by using a standard event study approach. Following Du and Boateng (2015), we use an event window of $(-1,1)$ and an estimation period of $(-240,-21)$ relative to the first announcement date of an acquisition $(t=0)$. The cumulative average abnormal returns (CAARs) are calculated using a one-factor market model (employing the value-weighted Shanghai and Shenzhen Composite Index as a market index). For robustness, we also consider the event windows $(0,1),(-2,2)$, and $(-3,3)$.

\footnotetext{
${ }^{9}$ First, we retrieve the chairman/CEO turnover information from CSMAR's China Listed Firms Corporate Governance Research Database. Next, we manually check the background information in the top managers' profiles provided by Stockstar to identify whether the turnover is considered political (i.e. whether the PC Index value increases).
} 
To examine the link between political connections and the market reaction to cross-border deal announcements, we estimate the following multivariate regression:

$$
\begin{aligned}
\text { CAR }_{i}= & \alpha_{i}+\beta_{1} \cdot \text { Political Connection }_{i}+\beta_{2} \cdot \text { Gov Index }_{i}+\beta_{j} \cdot \sum_{j} \text { Distance }_{j, i}+\beta_{k} \\
& \sum_{k} \text { Deal Characteristics } \\
k, i & +v_{n} \cdot \boldsymbol{N}_{i, n}+\varphi_{k}+\pi_{t}+\varepsilon_{i}
\end{aligned}
$$

where $C A R_{i}$ is the cumulative abnormal return of the acquiring POE $i$ during the period starting one day before and ending one day after the cross-border deal announcement. The independent variables are the same as in equation (1) with the addition of $j$ Distance measures, which represents differences in the two cultural dimension measures (Hofstede and Culture Distance), and $k$ Deal Characteristics, which include the target size (Deal Size), the method of payment (All Cash Deal and All Stock Deal), the listing status of the target company (Public Target), and the legal system of the target's home country (Common Law). According to our hypothesis, if the politically connected top managers of POEs tend to build their political capital at the expense of shareholder interests, we expect the coefficients on the political connection variables Connection and PC Index $\left(\beta_{1}\right)$ to be negative.

To complete the picture, we also examine the accounting performance of POEs, measured by $R O E$, after completing a cross-border M\&A transaction. However, the decisions to hire politically connected top executives and to become active in acquiring foreign companies are likely to be made simultaneously in an equilibrium setting. This raises a potential endogeneity concern, which ideally would be overcome by finding a suitable instrument. Unfortunately, we were not successful in finding or constructing a convincing instrument. Consequently, the coefficients can be interpreted as indicating correlation only. 
We compare the financial performance of (politically connected) acquiring companies during the three-year period after completion of the cross-border M\&A deal with the performance of nonacquiring POEs. The model is specified as follows:

$$
\begin{aligned}
\text { ROE }_{i, t}= & \alpha+\beta_{1} \cdot \text { Connection }_{i, t}+\beta_{2} \cdot \text { Post CBMA }_{i, t}+\beta_{3} \cdot \text { Post CBMA } \times \text { Connection }_{i, t}+ \\
& \beta_{4} \cdot \text { Gov Index } \\
i, t & +\beta_{5} \cdot \text { Multi Acquirer }_{i, t}+\boldsymbol{v}_{i, t} \cdot \mathbf{N}_{i, \boldsymbol{n}, \boldsymbol{t}}+\varphi_{i}+\pi_{k}+\varepsilon_{i, t}
\end{aligned}
$$

where the dependent variable is the ROE of firm $i$ and Post CBMA is a dummy variable that equals 1 if POE $i$ completed a cross-border M\&A between years $t$ and $t+3$, and 0 otherwise. Multi Acquirer is a dummy variable that equals 1 if firm $i$ acquires more than one overseas target starting in year $t$ when the second acquisition is completed until the end of the observation period, and 0 otherwise. All other variables are as defined in equation (1). Our main coefficient of interest is that for the interaction term, $\beta_{3}$. If politically connected POEs tend to incur moral hazard problems by engaging in political empire building, we expect $\beta_{3}$ to be negative and statistically significant. In other words, we expect the effect of political connections on firm performance to decrease for POEs that have completed a cross-border M\&A transaction.

\section{Empirical Results}

\subsection{Descriptive Statistics}

Panel A of Table 1 shows the annual number of Chinese POEs entering the global market via a cross-border M\&A transaction for the first time between 2007 and 2016. In total, there are 288 Chinese POEs that complete foreign acquisitions during our sample period. The annual percentage of newly acquiring POEs during our sample period increased substantially in 2011 and peaked at $21.53 \%$ in 2015, with sixty-two POEs entering the international market. However, 2016 saw a 
significant drop in that number, presumably because of the economic slowdown in China during that year. Panel B of Table 1 displays the number of cross-border deals completed by Chinese POEs and shows that the vast majority (about three-quarters) of POEs completed only one deal, about 18 percent two deals and only about five percent engaged in more than two acquisitions.

\section{-Please insert Table 1 about here-}

Table 2 specifies the countries of origin of the target companies acquired by Chinese POEs. The targets are geographically spread around the world. However, the majority are from major world economies such as Australia, Canada, Japan, Germany, the U.K., and the U.S. Interestingly, most POEs in China seem to extend their business to countries that are not politically "close" to the Chinese government. This is in contrast to the situation for SOEs which, according to the findings of Ramasamy, Yeung, and Laforet (2012), are more attracted to countries that have closer bilateral political relationships with China and/or are natural resources-based. This underlines our earlier argument that POEs tend to be market seekers. Their motivations for going global are based on technology and strategy, as demonstrated by our sample.

\section{-Please insert Table 2 about here-}

Table 3 provides descriptive statistics for the company characteristics of non-acquisitive and acquisitive POEs (see Table A1 in the appendix for variable definitions). Our sample consists of 1,494 non-acquisitive POEs (7,975 firm-year observations) and 288 acquisitive POEs (385 firmyear observations). We note that, in China, only a small percentage of POEs have entered the international markets.

For acquisitive POEs, we can clearly see that a majority of the firms are politically connected to the government, regardless of which index is used (i.e. Connection or the PC Index). The mean 
of Connection (0.405) implies that about $40 \%$ of acquisitive POEs have political ties. The differences in Connection and the PC Index between non-acquisitive and acquisitive POEs are statistically significant at the $1 \%$ level, providing univariate support for Hypothesis 1, i.e. that politically connected POEs are more likely to complete cross-border M\&A deals than unconnected POEs. However, we find no univariate evidence that the corporate governance (Gov Index) of acquisitive POEs is higher than that of non-acquisitive POEs (Hypothesis 2). We will explore this factor further in our multivariate analyses.

For the control variables, we find that acquisitive POEs are on average more profitable (ROA), larger (Size), and have lower growth opportunities (Tobin's q) than non-acquisitive POEs. In addition, we find that non-acquisitive firms have stronger ownership-based political connections, measured by the variables $L B H$ Connection and Multi BH Connections. A lower level of state ownership may help acquisitive POEs in the sense that they could be perceived as less government connected. The correlation matrices in Table 4 show that the pairwise correlations are not greater than 0.5 . To further unveil any potential multicollinearity issues, we also calculate the Variance Inflation Factors (VIF) in our multivariate regressions. In line with our bivariate correlation analysis, multicollinearity does not appear to pose any problems in a multivariate context.

-Please insert Tables 3 and 4 about here-

\subsection{Political Connections and M\&A Engagement by POEs}

To investigate the link between political connections and the probability of becoming acquisitive in international markets, we show the results of a fixed-effects panel logit regression in Table 5. Our baseline results in column 1 indicate that politically connected POEs are more likely to acquire overseas companies. The coefficient of Connection is 1.474 and statistically significant at the $1 \%$ 
level. Column 2 shows the results when measuring political connections via the PC Index, which likewise supports Hypothesis 1, i.e. that the likelihood of completing a cross-border M\&A transaction increases with the strength of political connections. However, we do not find any statistical support for Hypothesis 2, namely that a firm with sounder corporate governance is more likely to complete a cross-border M\&A deal.

\section{-Please insert Table 5 about here-}

Next, to have a one-to-one comparison, we perform cross-sectional logistic regressions based on a balanced matched sample of acquisitive and non-acquisitive POEs using the PSM method. The results in Table 6 (Panels A and B) indicate that after matching, the firm characteristics of nonacquisitive POEs are not statistically different from those of acquisitive POEs. Thus, the sample is well-balanced.

Using this balanced sample, the baseline results in column 1 (Table 7) indicate that politically connected POEs are more likely to acquire overseas companies. The coefficient of Connection is 0.472 , which is statistically significant at the $5 \%$ level. The related marginal effect reveals that the predicted probability of becoming an acquisitive POE increases from $45.8 \%$ by 11.5 percentage points (equivalent to a relative increase of $25.1 \%$ ) when hiring a politically connected top manager. Similar results are obtained when measuring political connections via the PC Index (column 2). The coefficient of the $P C$ Index is 0.185 , also statistically significant at the $5 \%$ level. Specifically, the predicted probability of becoming a cross-border bidder is $46.3 \%$ when the $P C$ Index is 0 . This probability increases by 4.6 percentage points (or $9.9 \%$ ) when the $P C$ Index increases from 0 to 1 , by $8.8 \%$ when the $P C$ Index increases from 1 to 2 , and by $7.9 \%$ when the $P C$ Index increases from 2 to 3 . Columns 3 and 4 show that comparable results are obtained when only the first cross-border 
deal of acquisitive POEs is included. In sum, these PSM results provide further support for Hypothesis 1, namely that politically connected POEs have a higher likelihood of entering the global market through cross-border M\&A deals. Furthermore, the results are both statistically and economically significant. They are in line with the intuition that the top managers of POEs are more likely to follow the government's call to go global by completing cross-border M\&A transactions if they have political connections. These POEs are also more likely to be able to manage the logistics of these transactions and to get preferential treatment by the government after completing a cross-border M\&A transaction. This is supported by our sample firms receiving on average an $83 \%$ percent higher loan volume in the two years after completing a cross-border M\&A deals than in the two years before (see Figure 1).

\section{-Please insert Tables 6 and 7 and Figure 1 about here-}

\subsection{Corporate Governance and M\&A Engagement by POEs}

To investigate the link between corporate governance and a POE's likelihood of acquiring an overseas target, we focus on the coefficient of the governance index (Gov Index). When performing post-matching cross-sectional analyses (see Table 7), this coefficient is positive and statistically significant, at least at the $10 \%$-level, indicating that POEs with higher corporate governance standards are more likely to acquire companies outside China (in line with Hypothesis 2). However, the Gov Index was not significant in the panel logistic regression setting in Table 5. Thus, we do not find robust empirical support for Hypothesis 2.

To address a potential endogeneity issue associated with the decision to become an acquisitive POE, we conduct a quasi-experiment in which we focus on the replacement of a CEO or chairman by a successor with stronger political ties than his or her predecessor (i.e. a higher $P C$ Index). We 
characterize these turnovers using the variable Political Turnover. If political connections result in a higher probability of acquiring a company outside China, we expect to find a higher likelihood of POEs entering the global markets after a political turnover. To ensure a balanced sample of acquisitive and non-acquisitive POEs, we run a similar PSM routine to that used previously, but also require the 288 firm-year observations (corresponding to the POEs' first cross-border deals) to have the same $P C$ Index as those in the control group. The diagnostic tests from Table 8 show that the PSM successfully balances the sample.

We again run a logit regression with the dependent variable of becoming an overseas acquisitive POE and a set of explanatory variables that include the Political Turnover dummy. The results (see Table 9) show that the coefficient of Political Turnover is positive and statistically significant, indicating that the likelihood of a POE proceeding with a cross-border M\&A significantly increases after a political turnover. This finding provides strong support for Hypothesis 1 and for a causal relationship between political connections and cross-border M\&A activities by Chinese POEs. -Please insert Tables 8 and 9 about here-

\subsection{The Financial Performance of Multinational POEs after Cross-border M\&As}

To explore how POEs fare after completing a cross-border acquisition, we first provide univariate results for an event study in which we examine the stock returns of acquisitive POEs around the announcement of a cross-border M\&A deal (see Table 10). We find that shareholders react positively to cross-border M\&A announcements with statistically significant CAARs between $1 \%$ and $1.9 \%$, depending on the event window. These findings are in line with Du and Boateng (2015) who find that shareholders react positively to cross-border M\&A deals by Chinese acquirers. Over similar event windows, their CAARs range from $0.45 \%$ to $0.64 \%$. However, their study pools 
SOEs and POEs together. Our results suggest that, overall, cross-border M\&A announcements by POEs generate higher abnormal returns. However, shareholders react differently depending on whether the cross-border M\&A deal is announced by firms with politically connected or ununconnected top management (Panel B). On average, we find that the announcement returns of politically connected POEs are $1.6 \%$ lower for all cross-border M\&A transactions and 1.9\% lower for the announcement of a first cross-border deal. These univariate findings match what we expect under Hypothesis 3, i.e. that politically connected top managers are more likely to engage in political empire-building behavior, which may not be in line with shareholder interests.

We complement these univariate findings with a multivariate analysis in which we control for deal characteristics as well as cultural differences between China and the country where the target company is domiciled (see Table 11). The results are consistent with the univariate analysis above. The announcement returns are on average about $1.6 \%$ lower for politically connected POEs. ${ }^{10,11}$ We interpret this as further support for Hypothesis 3, namely that investors may believe that a politically connected top management has other (e.g. political) motives when completing crossborder M\&A transactions instead of focusing purely on shareholder wealth maximization. In additional analyses we tested indirectly if the acquisition is related to strategic asset seeking. To do

\footnotetext{
${ }^{10}$ To ensure the robustness of our results, we also examine the CARs for other event windows; the empirical results remain qualitatively unchanged. The respective results are available from the authors upon request.

${ }^{11}$ Differences in the cross-border acquisition announcement returns for politically connected and unconnected POEs may be driven by differences in the completion probability. All of our announcements resulted in completed deals, but this is clearly unknown ex ante. We check CSMAR's Merger \& Acquisition, Asset Restructuring Research Database for failed cross-border M\&A deals to determine the difference in deal completion probability between the two cases (i.e. when top management is and is not politically connected). We find that deal failure is quite uncommon for POEs and occurred only twelve times during our observation period. Among these twelve POEs, five had politically connected top managers. Given that there are comparatively few deal failures relative to the number of completed deals, it seems unlikely that market participants would assume a high probability of deal failure. However, even if they do price it in, the probability of failure among politically connected and non-connected POEs is almost evenly distributed. Therefore, market participants would be unable to infer any information about the probability of deal failure from knowledge of the political connectedness of top management.
} 
so, we compared the difference in Research Intensity between POEs that have completed a crossborder M\&A and propensity-score-matched "control" firms that are not active in the acquisition market (see Proelss et al., 2017). We find that the average two-year Research Intensity of acquisitive POEs after deal completion is 1.3 percentage points higher than that of control firms ( $\mathrm{p}$-value $=0.008)$. We interpret this as evidence that POEs that gain access to "cutting-edge technology" through cross-border acquisitions need to increase their R\&D spending to successfully employ that technology in China (see Wu, 2015).

The only deal characteristic that is statistically significantly related to the observed announcement returns is a deal payment by cash only (All Cash Deal). This positive relationship is well documented in the literature (see Travlos, 1987; Fishman, 1989; Brown and Ryngaert, 1991; Martin, 1996; and Fuller, Netter, and Stegemoller, 2002).

\section{-Please insert Tables 10 and 11 about here-}

To examine a POE's financial performance during the three-year period after it has completed a cross-border deal, we calculate the return on equity $(R O E)$ for acquisitive and non-acquisitive POEs. Our main variable of interest is the interaction term Post CBMA $\times$ Connection. The coefficients of Connection and the interaction term (Post CBMA $\times$ Connection) are 0.054 and 0.198 , respectively, and are both statistically significant at the $1 \%$ level (see Table 12). This indicates an underperformance of about 14 percentage points (0.054-0.198), measured by $R O E$, of politically connected POEs relative to non-connected POEs during the three-year period after completing a cross-border M\&A deal. Notwithstanding the potential endogeneity concern, this result is consistent with our political connection trade-off theory (and Hypothesis 3), under which politically connected top managers complete cross-border M\&A deals largely as a means of 
political empire building. This may occur at the expense of shareholder value, and may thus be associated with a decrease in the POE's firm value. The coefficient of post CBMA is positive and significant at the $5 \%$-level, which is consistent with our univariate evidence showing that, on average, investors react positively to cross-border M\&A announcements. We also find that serial acquirers have statistically significantly higher accounting performance than one-time acquirers after completing a cross-border M\&A deal, which could be explained by learning gains through serial acquisitions (cf., Aktas, Bodt and Roll, 2013).

\section{-Please insert Table 12 about here-}

\subsection{Robustness Checks}

Our first set of robustness checks focuses on an alternative explanation for the importance of political connections, namely that ownership-level political connections matter more than those of the top management. To rule out this alternative explanation, we re-estimate the previous panel logistic regressions, the cross-sectional logit regressions, and the quasi-experiment while also including two ownership-level political connection variables (LBH Connection and Multi BH Connections). The results show that neither LBH Connection nor Multi BH Connections is statistically significantly positively related to the likelihood of completing a cross-border M\&A deal (see Table A2 in the appendix). Moreover, the coefficients for the top management political connection variables (Connection and PC Index) do not change substantially and remain statistically significant at least at the $5 \%$ level. Similarly, when we re-perform our quasi-experiment (see Table A3 in the appendix), we find that the replacement of a blockholder by a new blockholder with stronger ties is unrelated to the probability of completing a cross-border M\&A transaction, unlike a political turnover of the top management (see Table 9). In sum, we find no evidence that 
ownership-based political connections increase the likelihood of a POE becoming acquisitive in foreign markets, while the political connections of top management continue to produce similar effects.

Furthermore, to address the potential influence of clustered or serial acquisitions by POEs, we checked for robustness by using a count model (i.e. panel and cross-sectional Poisson regressions) in which the dependent variable is the number of overseas targets acquired by POEs (see Table A4 in the appendix). Some of these model specifications also control for ownership-level political connections. We find that political connections (measured by Connection and the PC Index) are statistically significantly positively related to the number of completed cross-border M\&A deals whereas ownership-level political connections show no association. Therefore, we do not find any evidence that the main results are driven by clustered or serial acquisitions.

Finally, we test for a potential interaction between political connections and a POE's corporate governance. Such an interaction might be expected if politically connected top managers tend to pursue cross-border M\&A deals for reasons other than maximizing shareholder value, such as maximizing political capital. In this context, we conjecture that higher corporate governance standards within a company limit top management's propensity for political empire building at the cost of shareholder value. For example, we expect the interaction term (Connection $x$ Gov Index) to have a positive coefficient in a regression of POEs' financial performance after a cross-border M\&A. In unreported results, we include this interaction term in all previous analyses and find that is has no statistical significance, regardless of the dependent variable in question (e.g. the likelihood of a cross-border M\&A or stock prices following cross-border M\&A announcements). One possible explanation is provided by Claessens and Fan (2002) who argue that corporate governance 
mechanisms have very limited effectiveness in systems with weak institutions. The arguably weak institutional environment in China seems to carry more weight than a sound corporate governance system; thus, the latter is neither able to block (value destroying) cross-border M\&A deals nor deter politically connected top managers from prioritizing their political capital over shareholder interests.

\section{Conclusion}

This study investigates the factors that affect the likelihood and consequences (in terms of firm performance) of cross-border M\&A transactions by Chinese POEs. Using a sample of 1,782 privately owned and publicly listed firms in China over the 2007-2016 period, we find strong empirical evidence that politically connected POEs have a greater chance of expanding their operations internationally through cross-border M\&A activities than POEs without such connections. This is in line with the first part of our political connection trade-off theory, namely that politically connected top managers are more motivated to carry out cross-border M\&A deals than their unconnected counterparts and are in a better position to handle the logistics. Our results hold after accounting for the potentially endogenous relationship between political connections and Chinese POEs' global expansion and after controlling for ownership-level political connections. However, we find at most weak support for the notion that sounder corporate governance increases a POE's probability of completing a cross border M\&A deal.

Finally, with respect to Chinese POEs' performance after announcing and completing a cross border M\&A deal, our results are consistent with the second part of our political connection tradeoff theory. We find that the average announcement returns of cross-border M\&A deals are lower for POEs in which the top managers are politically connected. We further show that accounting 
performance (measured by ROE) in the three-year period after deal completion is poorer for connected than for unconnected POEs. These findings provide empirical support for the anecdotal evidence (reported in the news) that top managers with political connections might be pursuing a political agenda and thereby create a moral hazard conflict at the expense of shareholder value.

Overall, our empirical analysis supports the notion that for emerging markets, the institutional environment affects POEs' decisions to become acquisitive in foreign markets. Specifically, it highlights the crucial role played by political connections in China in facilitating POEs' outbound FDI. When operating in an institutional environment that features excessive favoritism toward SOEs, building political ties can be an effective way of overcoming market discrimination and obtaining state-controlled financial resources. In other words, establishing political connections allows Chinese POEs to receive preferential treatment from the Chinese government in completing the financial and bureaucratic activities necessary for successful cross-border M\&A (for example, obtaining credit from state-owned banks, obtaining tax rebates, and simplifying the tedious and complex "going global" approval process). However, this may come at the cost of politically connected top managers overweighing their objective to create political capital while ignoring shareholder interests. In sum, the outcomes of this study are as expected under the political connection trade-off theory. 


\section{References}

ABC (2015, November 23). Port of Darwin: This is about more than China's economic interest. Available at: http://www.abc.net.au/news/2015-11-24/wade-the-darwin-port-is-anotherlink-in-chinas-expansion/6967640 (Accessed on August 20, 2017).

Adhikari, A., Derashid, C., \& Zhang, H. (2006). Public policy, political connections, and effective tax rates: Longitudinal evidence from Malaysia. Journal of Accounting and Public Policy 25(5), 574-595.

Agrawal, A., \& Knoeber, C. R. (1996). Firm performance and mechanisms to control agency problems between managers and shareholders. Journal of Financial and Quantitative Analysis 31(3), 377-397.

Aktas, N., Bodt, E., \& Roll, R. (2013). Learning from repetitive acquisitions: Evidence from the time between deals. Journal of Financial Economics 108(1), 99-117.

Antkiewicz, A., \& Whalley, J. (2006). Recent Chinese buyout activity and the implications for global architecture (No. w12072). National Bureau of Economic Research.

Berger, P. G., Ofek, E., \& Yermack, D. L. (1997). Managerial entrenchment and capital structure decisions. Journal of Finance 52(4), 1411-1438.

Bloom, N., Genakos, C., Sadun, R., \& Van Reenen, J. (2012). Management practices across firms and countries. Academy of Management Perspectives 26(1), 12-33.

Bloomberg (2016, March 30). Good Reason to Beware Chinese Buyers. Available at: https://origin-www.bloombergview.com/articles/2016-03-30/why-u-s-companies-shouldbeware-chinese-buyers (Accessed on August 20, 2017).

Bloomberg (2017, July 19). China's Buying Spree Ends Badly. Available at: https://www.bloomberg.com/view/articles/2017-07-20/china-s-buying-spree-ends-badly (Accessed on August 20, 2017).

Brown, D. T., \& Ryngaert, M. D. (1991). The mode of acquisition in takeovers: Taxes and asymmetric information. Journal of Finance 46(2), 653-669.

Brown, L. D., \& Caylor, M. L. (2006). Corporate governance and firm valuation. Journal of Accounting and Public Policy 25(4), 409-434.

Brown, P., Beekes, W., \& Verhoeven, P. (2011). Corporate governance, accounting and finance: A review. Accounting \& Finance 51(1), 96-172.

Bunkanwanicha, P., \& Wiwattanakantang, Y. (2009). Big business owners in politics. Review of Financial Studies 22(6), 2133-2168.

Charumilind, C., Kali, R., \& Wiwattanakantang, Y. (2006). Connected lending: Thailand before the financial crisis. Journal of Business 79(1), 181-218.

Chen, C. J., Li, Z., Su, X., \& Sun, Z. (2011). Rent-seeking incentives, corporate political connections, and the control structure of private firms: Chinese evidence. Journal of Corporate Finance 17(2), 229-243.

Cheng, L. K., \& Ma, Z. (2010). China's outward foreign direct investment. In: China's Growing Role in World Trade (pp. 545-578). University of Chicago Press.

China Daily. (2016, September 23). ODI led for first time by private firms. Available at: http://usa.chinadaily.com.cn/business/2016-09/23/content 26870001.htm (accessed on February 15, 2017). 
Claessens, S., \& Fan, J. P. (2002). Corporate governance in Asia: A survey. International Review of Finance 3(2), 71-103.

Claessens, S., Feijen, E., \& Laeven, L. (2008). Political connections and preferential access to finance: The role of campaign contributions. Journal of Financial Economics 88(3): 554-580.

Conyon, M. J., \& Peck, S. I. (1998). Board control, remuneration committees, and top management compensation. Academy of Management Journal 41(2), 146-157.

Core, J. E., Holthausen, R. W., \& Larcker, D. F. (1999). Corporate governance, chief executive officer compensation, and firm performance. Journal of Financial Economics 51(3), 371-406.

Deng, P. (2009). Why do Chinese firms tend to acquire strategic assets in international expansion? Journal of World Business 44(1), 74-84.

Ding, S., Wu, Z., Li, Y., \& Jia, C. (2010). Executive compensation, supervisory boards, and China's governance reform: A legal approach perspective. Review of Quantitative Finance and Accounting 35(4), 445-471.

Du, M., \& Boateng, A. (2015). State ownership, institutional effects and value creation in crossborder mergers \& acquisitions by Chinese firms. International Business Review 24(3), 430-442.

Dutordoir, M., Strong, N., \& Ziegan, M. C. (2014). Does corporate governance influence convertible bond issuance? Journal of Corporate Finance 24 (Convertible Bond Financing Special Issue), 80-100.

Faccio, M. (2006). Politically connected firms. American Economic Review 96(1): 369-386.

Fan, J. P., Wong, T. J., \& Zhang, T. (2007). Politically connected CEOs, corporate governance, and post-IPO performance of China's newly partially privatized firms. Journal of Financial Economics 84(2), 330-357.

Financial Times (2016, February 23). Tsinghua kills \$3.8bn investment plan in Western Digital. Available at: https://www.ft.com/content/c235a154-da37-11e5-98fd-06d75973fe09 (Accessed on August 20, 2017).

Financial Times. (2012, November 14). PE allied with Chinese privately-owned enterprises for jointly "going abroad.” Available at: http://www.ftchinese.com/story/001047477 (accessed on February 15, 2017).

Firth, M., Fung, P. M., \& Rui, O. M. (2007). Ownership, two-tier board structure, and the informativeness of earnings: Evidence from China. Journal of Accounting and Public Policy 26(4), 463-496.

Fishman, M. J. (1989). Preemptive bidding and the role of the medium of exchange in acquisitions. Journal of Finance 44(1), 41-57.

Fisman, R. (2001). Estimating the value of political connections. American Economic Review 91(4), 1095-1102.

Fuller, K., Netter, J., \& Stegemoller, M. (2002). What do returns to acquiring firms tell us? Evidence from firms that make many acquisitions. Journal of Finance 57(4), 1763-1793.

Gao, L., \& Kling, G. (2008). Corporate governance and tunneling: Empirical evidence from China. Pacific-Basin Finance Journal 16(5), 591-605. 
Gompers, P., Ishii, J., \& Metrick, A. (2003). Corporate governance and equity prices. Quarterly Journal of Economics 118(1), 107-155.

Guariglia, A., Liu, X., \& Song, L. (2011). Internal finance and growth: Macroeconometric evidence on Chinese firms. Journal of Development Economics 96(1), 79-94.

Hofstede, G. (1980). Culture's consequences: International differences in work-related values. Beverly Hills CA, Sage Publications.

Huang, W., Jiang, F., Liu, Z., \& Zhang, M. (2011). Agency cost, top executives' overconfidence, and investment-cash flow sensitivity: Evidence from listed companies in China. PacificBasin Finance Journal 19(3), 261-277.

Huang, X., \& Chi, R. (2014). Chinese private firms' outward foreign direct investment: Does firm ownership and size matter? Thunderbird International Business Review 56(5), 393406.

Jia, C., Ding, S., Li, Y., \& Wu, Z. (2009). Fraud, enforcement action, and the role ofcorporate governance: Evidence from China. Journal of Business Ethics 90(4), 561-576.

Jiang, F., \& Kim, K. A. (2015). Corporate governance in China: A modern perspective. Journal of Corporate Finance 32, 190-216.

Jiang, F., Huang, J., \& Kim, K. A. (2013). Appointments of outsiders as CEOs, state-owned enterprises, and firm performance: Evidence from China. Pacific-Basin Finance Journal 23, 49-64.

Khwaja, A. I., \& Mian, A. (2005). Do lenders favor politically connected firms? Rent provision in an emerging financial market. Quarterly Journal of Economics 120(4), 1371-1411.

Kim, K. A., Kitsabunnarat-Chatjuthamard, P., \& Nofsinger, J. R. (2007). Large shareholders, board independence, and minority shareholder rights: Evidence from Europe. Journal of Corporate Finance 13(5), 859-880.

Kostova, T. (1999). Transnational transfer of strategic organizational practices: A contextual perspective. Academy of Management Review 24(2), 308-324.

La Porta, R., Lopez-de-Silanes, F., Shleifer, A., \& Vishny, R. (1998). Law and finance. Journal of Political Economy 106(6), 1113-1155.

La Porta, R., Lopez-de-Silanes, F., Shleifer, A., \& Vishny, R. (2000). Investor protection and corporate governance. Journal of Financial Economics 58(1), 3-27.

Li, G., \& Zhou, H. (2015). Political connections and access to IPO markets in China. China Economic Review 33, 76-93.

Li, H., Meng, L., Wang, Q., \& Zhou, L. A. (2008). Political connections, financing and firm performance: Evidence from Chinese private firms. Journal of Development Economics 87(2), 283-299.

Linklaters (2017, March 19). Up to a third of Chinese outbound M\&A deals by value blocked or withdrawn in 2016. Available at: http://www.linklaters.com/News/LatestNews/2017/ Pages/third-Chinese-outbound-MA-deals-value-blocked-withdrawn-2016.aspx (Accessed on August 20, 2017).

Liu, J., \& Tan, B. (2004). The competitive advantages of Chinese SMEs. Overseas Investment 12, 75-77 (in Chinese). 
Lu, J. Y., Liu, X. H., Wright, M., \& Filatotchev, I. (2014). International experience and FDI location choices of Chinese firms: The moderating effects of home country government support and host country institutions. Journal of International Business Studies 45(4), 428-449.

Luo, D., \& Liu, X. (2009). Political connections, entry barriers and corporate performance: Empirical evidence from publicly-traded private-controlling firms in China. Guanli Shijie (Management World) 5, 97-106 (in Chinese).

Luo, D., \& Zhen, L. (2008). Private control, political relationship and financing constraints of private listed enterprises. Journal of Financial Research 12, 164-178 (in Chinese).

Luo, Y., Xue, Q., \& Han, B. (2010). How emerging market governments promote outward FDI: Experience from China. Journal of World Business 45(1), 68-79.

Martin, K. J. (1996). The method of payment in corporate acquisitions, investment opportunities, and management ownership. Journal of Finance 51(4), 1227-1246.

Mayer, T., \& Zignago, S. (2011). Notes on CEPII's distances measures: The GeoDist database.

Meyer, J. W., \& Rowan, B. (1977). Institutionalized organizations: Formal structure as myth and ceremony. American Journal of Sociology 83(2), 340-363.

Morck, R., Yeung, B., \& Zhao, M. (2008). Perspectives on China's outward foreign direct investment. Journal of International Business Studies 39(3), 337-350.

New York Times (2016, October 24). Germany Withdraws Approval for Chinese Takeover of Aixtron. Available at: https://www.ft.com/content/c235a154-da37-11e5-98fd06d75973fe09 (Accessed on August 20, 2017).

Peng, M. W., Wang, D. Y. L., \& Jiang, Y. (2008). An institution-based view of international business strategy: A focus on emerging economies. Journal of International Business Studies 39 (5), 920-936.

Peng, W. Q., Wei, K. J., \& Yang, Z. (2011). Tunneling or propping: Evidence from connected transactions in China. Journal of Corporate Finance 17(2), 306-325.

Poncet, S., Steingress, W., \& Vandenbussche, H. (2010). Financial constraints in China: Firmlevel evidence. China Economic Review 21(3), 411-422.

Proelss, J., Schweizer, D., \& Zhan, F. (2017). China: From imitator to innovator? Available at SSRN: https://ssrn.com/abstract=2846428.

Ramasamy, B., Yeung, M., \& Laforet, S. (2012). China's outward foreign direct investment: Location choice and firm ownership. Journal of World Business 47(1), 17-25.

Rediker, K. J., \& Seth, A. (1995). Boards of directors and substitution effects of alternative governance mechanisms. Strategic Management Journal 16(2), 85-99.

Regner, P., \& Edman, J. (2014). MNE institutional advantage: How subunits shape, transpose and evade host country institutions. Journal of International Business Studies 45(3), 275 302.

Roberts, B. E. (1990). A dead senator tells no lies: Seniority and the distribution of federal benefits. American Journal of Political Science 34(1), 31-58.

Rui, H. C., \& Yip, G. S. (2008). Foreign acquisitions by Chinese firms: A strategic intent perspective. Journal of World Business 43(2), 213-226. 
Saich, T. (2015). The National People's Congress: Functions and membership. Harvard Kennedy School Working Paper, Available at http://ash.harvard.edu/files/ash/files/the_national_peoples_congress.pdf.

Schweizer, D., Walker, T. J., \& Zhang, A. (2016). Do privately owned enterprises in China need political connections to issue corporate bonds? Unpublished Working Paper.

Available at: SSRN: https://ssrn.com/abstract=2846730

Shan, Y. G. (2015). Value relevance, earnings management and corporate governance in China. Emerging Markets Review 23, 186-207.

Sina Finance (2010, March 8). Hongwei Zhang (CPPCC) suggests to diversify the method of overseas investment on energy. Available at: http://news.sina.com.cn/c/2010-0308/120919815889.shtml (Accessed on August 20, 2017). (in Chinese)

Sina Finance (2016, October 8). The cross-border M\&A of Chinese companies have been experiencing exponential growth, but only $13 \%$ of the deals are profitable. Available at: http://finance.sina.com.cn/roll/2016-10-08/doc-ifxwrhpm2611573.shtml (Accessed on August 20, 2017). (in Chinese)

Sina Finance. (2016, December 26). 65 list firms have completed cross-border mergers and acquisitions this year: privately owned enterprises account for nearly 70\%. Available at: http://finance.sina.com.cn/roll/2016-12-26/doc-ifxyxvcr7574949.shtml (accessed on February 15, 2017) (in Chinese).

South China Morning Post (2017, July 6). Germany's football diplomacy delights beaming Xi Jinping as Chinese president and Angela Merkel watch kids' match in Berlin. Available at: http://www.scmp.com/sport/soccer/article/2101554/germanys-football-diplomacydelights-beaming-xi-jinping-chinese (Accessed on August 20, 2017).

Sun, Z., Vinig, T., \& Hosman, T. D. (2017). The financing of Chinese outbound mergers and acquisitions: Is there a distortion between state-owned enterprises and privately owned enterprises? Research in International Business and Finance 39, 377-388.

Sutherland, D., \& Ning, L. (2011). Exploring “onward-journey" ODI strategies in China's private sector businesses. Journal of Chinese Economic and Business Studies: 9(1), 43-65.

The Globe and Mail (2017, July 21). Chinese firm expelled from trade association days before takeover of Canadian high-tech company. Available at: https://beta.theglobeandmail.com/news/politics/chinese-firm-expelled-from-tradeassociation-days-before-takeover-of-canadian-high-tech-company/article35758019/ (Accessed on August 20, 2017).

The Telegraph (2017, July 12). Germany moves to block takeovers by foreign investors. Available at: http://www.telegraph.co.uk/business/2017/07/12/germany-moves-block-takeoversforeign-investors/ (Accessed on August 20, 2017).

Thomsen, S., Pedersen, T., \& Kvist, H. K. (2006). Blockholder ownership: Effects on firm value in market and control based governance systems. Journal of Corporate finance 12(2), 246-269.

Travlos, N. G. (1987). Corporate takeover bids, methods of payment, and bidding firms' stock returns. Journal of Finance 42(4), 943-963. 
United Nations Conference on Trade and Development (2016). World Investment Report 2016: Investor Nationality: Policy Challenges, United Nations, Geneva.

Vafeas, N. (1999). Board meeting frequency and firm performance. Journal of Financial Economics 53(1), 113-142.

Voulgaris, G., Stathopoulos, K., \& Walker, M. (2010). Compensation consultants and CEO pay: UK evidence. Corporate Governance: An International Review 18(6), 511-526.

Waelchli, U., \& Zeller, J. (2013). Old captains at the helm: Chairman age and firm performance. Journal of Banking \& Finance 37(5), 1612-1628.

Wu, W., Wu, C., \& Rui, O. M. (2012). Ownership and the value of political connections: Evidence from China. European Financial Management 18(4), 695-729.

Wu, X. (2015). Effect of overseas M\&A on China's technological innovation capability. Working paper, Zhejiang University.

Xiao, J., \& Sun, F. (2005). The challenges facing outbound Chinese M\&As. International Financial Law Review 24(12), 44-46.

Yermack, D. (1996). Higher market valuation of companies with a small board of directors. Journal of Financial Economics 40(2), 185-211.

Yi, Z., Yu, S., \& Jiang, F. (2011). Busy board: Dedication or poor efficiency? Finance \& Trade Economics 12, 1-13 (in Chinese).

Young, M. N., Peng, M. W., Ahlstrom, D., Bruton, G. D., \& Jiang, Y. (2008). Corporate governance in emerging economies: A review of the principal-principal perspective. Journal of Management Studies 45(1), 196-220.

Yu, M., \& Pan, H. (2008). Political connections, institutional environment and privately-owned enterprises' access to bank loans. Guanli Shijie (Management World) 8, 9-20 (in Chinese).

Yuan, C., Jing, X., \& Liao, G. (2010). State ownership of corporate and unsecured loans: Government intervention, implicit collateral or information advantage? Kuaiji Yanjiu (Journal of Accounting Research) 8, 49-54 (in Chinese). 


\section{Figure 1: Bank Loan Volume of POEs before and after Cross-border M\&A Transactions}

This figure shows the mean bank loan volume (in million Chinese Yuan) POEs receive before and after the completion of a cross-border merger or acquisition (CBMA), based on 203 observations for which bank loan data are available in CSMAR's Bank Loan Research Database.

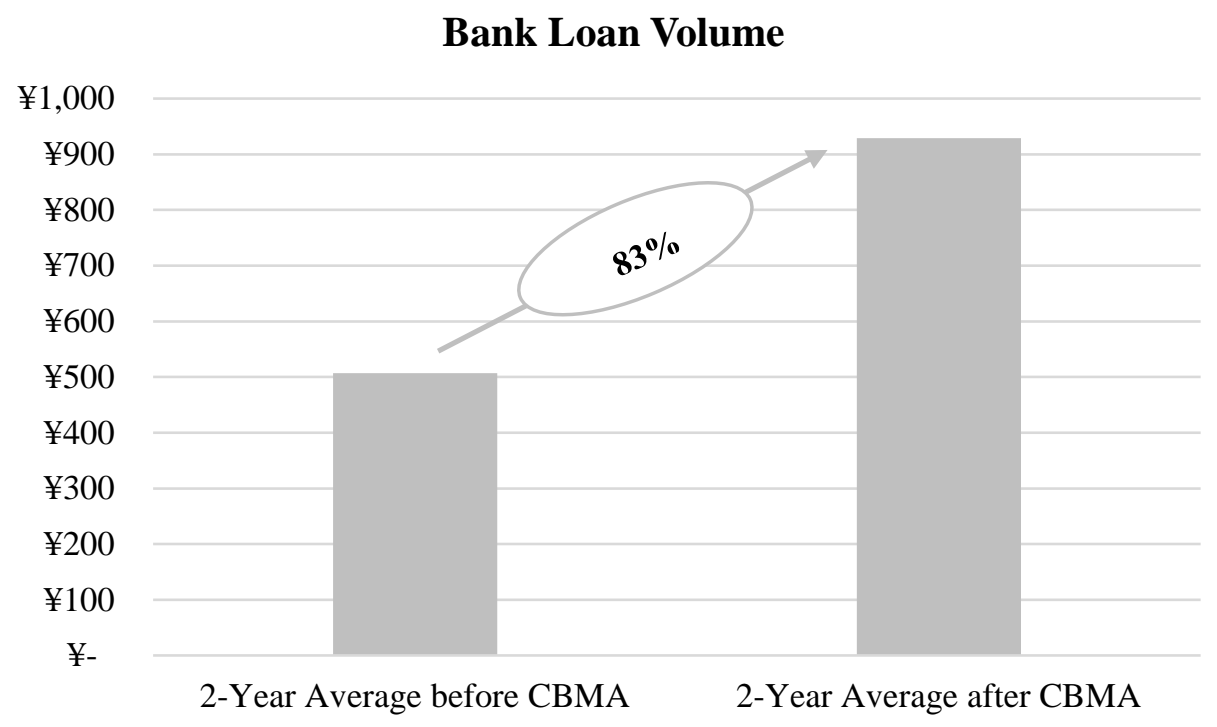




\section{Table 1: Overview of Cross-border M\&A Transactions by Chinese POEs}

Panel A of this table reports the number of Chinese POEs completing a cross-border M\&A transaction for the first time by year, along with percentages, between 2007 and 2016. Chinese POE data are retrieved from the CSMAR database. Panel B shows the distribution of the number of completed cross-border M\&A transactions for acquiring POEs.

\section{Panel A:}

\begin{tabular}{ccc}
\hline Year & Number of Acquiring POEs & Percentage (\%) \\
\hline 2007 & 12 & 4.17 \\
2008 & 12 & 4.17 \\
2009 & 13 & 4.51 \\
2010 & 22 & 7.64 \\
2011 & 32 & 11.11 \\
2012 & 42 & 14.58 \\
2013 & 32 & 11.11 \\
2014 & 28 & 9.72 \\
2015 & 62 & 21.53 \\
2016 & 33 & 11.46 \\
\hline Total & $\mathbf{2 8 8}$ & $\mathbf{1 0 0 . 0 0}$
\end{tabular}

\section{Panel B:}

\begin{tabular}{|c|c|c|}
\hline $\begin{array}{c}\text { Number of Completed } \\
\text { Cross-border M\&A Deals }\end{array}$ & Number of POEs & Percentage $(\%)$ \\
\hline 1 & 219 & 76.04 \\
\hline 2 & 52 & 18.06 \\
\hline 3 & 10 & 3.47 \\
\hline 4 & 5 & 1.74 \\
\hline 5 & 1 & 0.35 \\
\hline 7 & 1 & 0.35 \\
\hline
\end{tabular}




\section{Table 2: Locations of the Targets Acquired by POEs}

Distribution of target countries for Chinese POEs operating as acquiring POEs between 2007 and 2016.

\begin{tabular}{|c|c|}
\hline Country of Acquired Target(s) & Number \\
\hline Argentina & 2 \\
\hline Australia & 25 \\
\hline Belgium & 1 \\
\hline Brunei & 2 \\
\hline Bulgaria & 1 \\
\hline Cambodia & 1 \\
\hline Canada & 14 \\
\hline Cyprus & 1 \\
\hline Czech Republic & 1 \\
\hline Denmark & 4 \\
\hline France & 7 \\
\hline Germany & 45 \\
\hline India & 1 \\
\hline Indonesia & 4 \\
\hline Israel & 1 \\
\hline Italy & 14 \\
\hline Japan & 39 \\
\hline Kazakhstan & 4 \\
\hline Liechtenstein & 1 \\
\hline Luxembourg & 3 \\
\hline Malaysia & 9 \\
\hline Mongolia & 1 \\
\hline Netherlands & 13 \\
\hline New Zealand & 1 \\
\hline North Korea & 1 \\
\hline Norway & 1 \\
\hline Pakistan & 1 \\
\hline Poland & 1 \\
\hline Portugal & 2 \\
\hline Singapore & 30 \\
\hline South Africa & 1 \\
\hline South Korea & 24 \\
\hline Spain & 2 \\
\hline Sweden & 3 \\
\hline Switzerland & 6 \\
\hline Thailand & 1 \\
\hline United Kingdom & 22 \\
\hline United States & 92 \\
\hline Uruguay & 2 \\
\hline Vietnam & 1 \\
\hline
\end{tabular}




\section{Table 3: Summary Statistics for all POEs}

This table reports summary statistics (mean, median, standard deviation, $25 \%$ and $75 \%$ quantiles, and the number of firm-year observations, $\mathrm{N}$ ) for all sample variables for non-acquiring POEs (Panel A) and acquiring POEs (Panel B) between 2007 and 2016. All variable definitions are as in Panel A of Table A1 in the appendix. Panel C reports the pairwise differences in means ( $t$-test) and medians (Wilcoxon test) of the variables between acquiring and nonacquiring POEs. Related $p$-values are shown to the right in parentheses. ${ }^{* * *}, * *$, and $*$ indicate statistical significance at the $1 \%, 5 \%$, and $10 \%$ levels, respectively.

\begin{tabular}{|c|c|c|c|c|c|c|}
\hline & Mean & Median & Std. Dev. & $25 \%$ & $75 \%$ & $\mathbf{N}$ \\
\hline \multicolumn{7}{|c|}{ Panel A: Non-acquiring POEs } \\
\hline Connection & 0.291 & 0.000 & 0.454 & 0.000 & 1.000 & 7,975 \\
\hline PC Index & 0.633 & 0.000 & 1.050 & 0.000 & 1.000 & 7,975 \\
\hline LBH Connection & 0.025 & 0.000 & 0.092 & 0.000 & 0.000 & 7,975 \\
\hline Multi BH Connections & 0.012 & 0.000 & 0.109 & 0.000 & 0.000 & 7,975 \\
\hline Gov Index & 3.337 & 3.000 & 1.213 & 3.000 & 4.000 & 7,975 \\
\hline ROA & 0.044 & 0.043 & 0.052 & 0.017 & 0.072 & 7,975 \\
\hline Leverage & 0.392 & 0.379 & 0.207 & 0.221 & 0.547 & 7,975 \\
\hline Firm Size & 21.345 & 21.235 & 0.915 & 20.679 & 21.911 & 7,975 \\
\hline Tobin's q & 2.941 & 2.383 & 1.729 & 1.693 & 3.697 & 7,975 \\
\hline Tangibility & 0.204 & 0.179 & 0.142 & 0.094 & 0.290 & 7,975 \\
\hline \multicolumn{7}{|c|}{ Panel B: Acquiring POEs } \\
\hline Connection & 0.405 & 0.000 & 0.492 & 0.000 & 1.000 & 385 \\
\hline PC Index & 0.901 & 0.000 & 1.164 & 0.000 & 2.000 & 385 \\
\hline LBH Connection & 0.017 & 0.000 & 0.083 & 0.000 & 0.000 & 385 \\
\hline Multi BH Connections & 0.003 & 0.000 & 0.051 & 0.000 & 0.000 & 385 \\
\hline Gov Index & 3.397 & 3.000 & 1.182 & 3.000 & 4.000 & 385 \\
\hline ROA & 0.056 & 0.051 & 0.055 & 0.026 & 0.081 & 385 \\
\hline Leverage & 0.390 & 0.399 & 0.206 & 0.215 & 0.540 & 385 \\
\hline Firm Size & 21.770 & 21.629 & 1.065 & 21.045 & 22.415 & 385 \\
\hline Tobin's q & 2.879 & 2.284 & 2.360 & 1.616 & 3.251 & 385 \\
\hline Tangibility & 0.208 & 0.182 & 0.142 & 0.094 & 0.306 & 385 \\
\hline Panel C: Differences & \multicolumn{2}{|c|}{ Differences in Means } & \multicolumn{3}{|c|}{ Differences in Medians } & \\
\hline Connection & $-0.1114^{* * *}$ & $(0.000)$ & $0.000^{* * *}$ & & & \\
\hline PC Index & $-0.268^{* * *}$ & $(0.000)$ & $0.000^{* * *}$ & & & \\
\hline LBH Connection & $0.009^{*}$ & $(0.064)$ & $0.000^{* * *}$ & & & \\
\hline Multi BH Connections & $0.009^{*}$ & $(0.091)$ & $0.000^{*}$ & & & \\
\hline Gov Index & -0.060 & $(0.343)$ & 0.000 & & & \\
\hline ROA & $-0.011^{* * * *}$ & $(0.000)$ & $-0.008^{* * *}$ & & & \\
\hline Leverage & 0.003 & $(0.816)$ & -0.020 & & & \\
\hline Firm Size & $-0.425^{* * *}$ & $(0.000)$ & $-0.394^{* * *}$ & & & \\
\hline Tobin's q & 0.062 & $(0.498)$ & $0.099^{* *}$ & & & \\
\hline Tangibility & -0.004 & $(0.570)$ & -0.003 & & & \\
\hline
\end{tabular}




\section{Table 4: Correlation Matrices}

This table reports the correlation coefficients between our sample variables for all POEs (Panel A) and for our subset of acquiring POEs (Panel B) between 2007 and 2016. $* * * * *$, and $*$ indicate statistical significance at the $1 \%, 5 \%$, and $10 \%$ levels, respectively.

Panel A:

\begin{tabular}{|c|c|c|c|c|c|c|c|c|c|c|c|}
\hline & (1) & (2) & (3) & (4) & (5) & (6) & (7) & (8) & (9) & (10) & (11) \\
\hline (1) CBMA & 1.000 & & & & & & & & & & \\
\hline (2) Connection & $0.052^{* * *}$ & 1.000 & & & & & & & & & \\
\hline (3) PC Index & $0.053^{* * *}$ & $0.938^{* * *}$ & 1.000 & & & & & & & & \\
\hline (4) LBH Connection & -0.020 & $-0.056^{* * *}$ & $-0.073^{* * *}$ & 1.000 & & & & & & & \\
\hline (5) Multi BH Connections & -0.018 & 0.018 & -0.006 & $0.317^{* * *}$ & 1.000 & & & & & & \\
\hline (6) Gov Index & 0.010 & $-0.066^{* * * *}$ & $-0.059^{* * * *}$ & $-0.022^{*}$ & 0.003 & 1.000 & & & & & \\
\hline (7) ROA & $0.046^{* * *}$ & $0.042^{* * * *}$ & $0.060^{* * * *}$ & $-0.058^{* * *}$ & -0.006 & 0.001 & 1.000 & & & & \\
\hline (8) Leverage & -0.003 & $0.058^{* * * *}$ & $0.038^{* * *}$ & $0.155^{* * *}$ & $0.060^{* * *}$ & $-0.035^{* *}$ & $-0.355^{* * *}$ & 1.000 & & & \\
\hline (9) Firm Size & $0.096^{* * *}$ & $0.154^{* * * *}$ & $0.145^{* * * *}$ & $0.038^{* * *}$ & $0.033^{* *}$ & $-0.046^{* * *}$ & $0.058^{* * *}$ & $0.396^{* * * *}$ & 1.000 & & \\
\hline (10) Tobin's q & -0.007 & $-0.076^{* * * *}$ & $-0.066^{* * *}$ & $-0.051^{* * *}$ & $-0.031^{* *}$ & $0.063^{* * *}$ & $0.250^{* * *}$ & $-0.299^{* * *}$ & $-0.335^{* * *}$ & 1.000 & \\
\hline (11) Tangibility & 0.006 & $0.030^{* *}$ & 0.007 & $0.103^{* * *}$ & 0.021 & $-0.068^{* * *}$ & $-0.171^{* * *}$ & $0.110^{* * *}$ & $-0.039^{* * *}$ & $-0.125^{* * *}$ & 1.000 \\
\hline
\end{tabular}

\section{Panel B:}

\begin{tabular}{|c|c|c|c|c|c|c|c|c|c|c|c|c|c|c|c|c|c|}
\hline & (1) & (2) & (3) & (4) & (5) & (6) & (7) & (8) & (9) & (10) & (11) & (12) & (13) & (14) & (15) & (16) & (17) \\
\hline (1) CAR & 1.00 & & & & & & & & & & & & & & & & \\
\hline (2) Connection & -0.13 & 1.00 & & & & & & & & & & & & & & & \\
\hline (3) PC Index & -0.13 & $0.94^{* * *}$ & 1.00 & & & & & & & & & & & & & & \\
\hline (4) Gov Index & -0.02 & 0.02 & 0.08 & 1.00 & & & & & & & & & & & & & \\
\hline (5) Hofstede & 0.01 & -0.08 & -0.10 & 0.04 & 1.000 & & & & & & & & & & & & \\
\hline (6) Culture Distance & -0.02 & 0.07 & $0.14^{*}$ & 0.01 & $-0.48^{* * * *}$ & 1.00 & & & & & & & & & & & \\
\hline (7) Multi Acquirer & 0.03 & 0.09 & 0.00 & $-0.15^{*}$ & 0.10 & -0.11 & 1.00 & & & & & & & & & & \\
\hline (8) Deal Size & 0.09 & 0.03 & 0.06 & 0.08 & -0.06 & 0.03 & 0.06 & 1.00 & & & & & & & & & \\
\hline (9) Public Target & -0.080 & $0.14^{*}$ & 0.11 & -0.00 & -0.07 & -0.02 & 0.04 & 0.03 & 1.00 & & & & & & & & \\
\hline (10) All_Cash Deal & 0.12 & -0.12 & -0.09 & -0.05 & 0.06 & 0.03 & -0.08 & -0.07 & 0.01 & 1.00 & & & & & & & \\
\hline (11) All Stock Deal & -0.06 & 0.08 & 0.06 & 0.04 & -0.09 & -0.07 & $0.14^{*}$ & 0.09 & -0.01 & $-0.71^{* * * *}$ & 1.00 & & & & & & \\
\hline (12) Common Law & -0.07 & -0.13 & -0.10 & 0.07 & $-0.43^{* * *}$ & $0.50^{* * *}$ & -0.07 & 0.00 & 0.05 & -0.00 & -0.07 & 1.00 & & & & & \\
\hline (13) ROA & 0.08 & -0.12 & -0.08 & -0.09 & -0.11 & 0.10 & -0.03 & -0.05 & -0.00 & 0.05 & -0.02 & -0.03 & 1.00 & & & & \\
\hline (14) Leverage & 0.00 & $0.19^{* * *}$ & $0.14^{*}$ & -0.05 & 0.07 & -0.08 & $0.17^{*}$ & 0.13 & -0.04 & -0.10 & 0.02 & -0.07 & $-0.36^{* * *}$ & 1.00 & & & \\
\hline (15) Firm Size & 0.03 & $0.23^{* * *}$ & $0.20^{* *}$ & -0.04 & 0.00 & -0.01 & $0.25^{* * *}$ & $0.23^{* * * *}$ & 0.09 & -0.02 & 0.08 & -0.07 & $-0.18^{*}$ & $0.54^{* * * *}$ & 1.00 & & \\
\hline (16) Tobin's q & 0.04 & -0.09 & -0.03 & 0.05 & -0.08 & 0.10 & -0.07 & -0.13 & 0.03 & 0.07 & -0.05 & 0.07 & $0.41^{* * *}$ & $-0.39^{* * * *}$ & $-0.29^{* * *}$ & 1.00 & \\
\hline (17) Tangibility & -0.11 & -0.05 & -0.03 & -0.05 & 0.07 & 0.03 & 0.07 & -0.05 & 0.04 & 0.04 & -0.01 & -0.04 & -0.00 & $0.19^{* * *}$ & 0.02 & -0.10 & 1.00 \\
\hline
\end{tabular}




\section{Table 5: The Effect of Political Influence on Becoming Acquisitive}

Results of a panel logit regression analysis for Chinese acquiring and non- acquiring POEs between 2007 and 2016. Chinese acquiring POEs are defined as those with at least one cross-border M\&A transaction within the sample period. The dependent variable is a dummy variable that equals 1 if the POE completes a cross-border M\&A deal in a given year, and 0 otherwise. See equation (1) for details. Column (1) reports the results using Connection as a proxy for political connections; column (2) uses the PC Index as a measure for political connections. We report coefficient estimates with $p$-values in parentheses below. Industry and Year Fixed Effects are included in both regressions. In the last two rows, we report the maximum and mean variance inflation factors (VIF). $* * *, * *$, and $*$ indicate statistical significance at the $1 \%, 5 \%$, and $10 \%$ levels, respectively.

\section{(1)}

(2)

\begin{tabular}{lcc}
\hline Connection & $1.474 * *$ & \\
PC Index & $(0.000)$ & \\
& & $0.557^{* * *}$ \\
Gov Index & & $(0.008)$ \\
& 0.029 & 0.027 \\
Firm Characteristics & $(0.624)$ & $(0.651)$ \\
Industry Fixed Effects & Yes & Yes \\
Year Fixed Effects & Yes & Yes \\
\hline Observations & Yes & Yes \\
Max VIF & 9,946 & 9,946 \\
Mean VIF & 1.46 & 1.46 \\
& 1.22 & 1.22 \\
\hline
\end{tabular}




\section{Table 6: Propensity Score Matching}

This table reports the results of a propensity score matching (PSM) routine for acquiring and nonacquiring Chinese POEs from 2007 to 2016. We match firms using a nearest neighbor propensity score matching algorithm and an array of firm-specific characteristics (ROA, Leverage, Firm Size, Tobin's q, Tangibility) in the year the POE completes its cross-border deal. Panel A reports the univariate balanced test results for pairs of treatment and control firms after matching. Panel B reports parameter estimates for the probit model used in estimating the propensity scores of the treated and control groups (where the treatment is a cross-border acquisition). We match firms in the year before completing a cross-border M\&A deal with non-acquiring POEs. The "Pre-Match" column contains the parameter estimates of the probit model estimated using the sample prior to matching. These estimates are then used to generate the propensity scores for matching acquiring and non-acquiring POEs. The "Post-Match" column contains the parameter estimates of the probit model estimated using the subsample of matched treatment-control pairs after matching. We match firms using a one-to-one nearest neighbor propensity score matching, without replacement. Definitions for all variables are provided in Panel A of Table A1 in the appendix. Industry and Year Fixed Effects are included in both regressions in Panel B. We report coefficient estimates with $p$-values in parentheses below. $* * *, * *$, and $*$ indicate statistical significance at the $1 \%$, $5 \%$, and $10 \%$ levels, respectively.

\begin{tabular}{lcccc}
\hline Panel A & Control & Treatment & Diff. & p-value \\
\hline ROA & 0.059 & 0.056 & 0.003 & 0.407 \\
Leverage & 0.393 & 0.390 & 0.003 & 0.839 \\
Firm Size & 21.799 & 21.770 & 0.029 & 0.697 \\
Tobin's q & 3.028 & 2.879 & 0.149 & 0.332 \\
Tangibility & 0.205 & 0.208 & -0.003 & 0.790 \\
\hline & & & \\
\hline Panel B & Pre-Match & Post-Match & -0.545 \\
\hline ROA & 0.783 & $(0.592)$ & \\
& $(0.170)$ & -0.027 & $(0.929)$ \\
Leverage & $-0.356^{* *}$ & -0.022 & \\
& $(0.030)$ & $(0.711)$ & \\
Firm Size & $0.303^{* * *}$ & -0.022 & \\
& $(0.000)$ & $0.417)$ & \\
Tobin's q & $0.033^{*}$ & -0.025 & \\
Tangibility & $(0.059)$ & $0.947)$ & \\
& 0.234 & 0.583 & \\
Constant & $(0.244)$ & $(0.649)$ & \\
& $-8.125^{* * *}$ & Yes & \\
\hline Industry Fixed Effects & $(0.000)$ & Yes & \\
Year Fixed Effects & Yes & 770 & \\
\hline Observations & Yes & 0.007 & \\
Pseudo R & 8,360 & 1.000 & \\
P-value of $\chi^{2}$ & 0.047 & & & \\
\hline
\end{tabular}


Table 7: The Effect of Political Influence on Becoming Acquisitive-A Crosssectional Analysis

This table reports the results of a post-matching logit regression analysis for Chinese acquiring and nonacquiring POEs between 2007 and 2016. Acquiring POEs are defined as those with at least one crossborder M\&A transaction within the sample period. Non-acquiring companies are the one-to-one nearest neighbors as defined in Table 6. The dependent variable is a dummy variable that equals 1 if the POE completes a cross-border M\&A deal in a given year, and 0 otherwise. See equation (1) for details. Columns (1) and (2) report the post-matching results using all cross-border deals; columns (3) and (4) report the post-matching results considering only the first cross-border deals for each acquiring POE. We report coefficient estimates with $p$-values in parentheses below. $p$-values are calculated using the clustered standard errors at the firm level for Columns (1) and (2). $p$-values are based on robust standard errors for columns (3) and (4). Industry and Year Fixed Effects are included in all regressions. In the last two rows, we report the maximum and mean variance inflation factors (VIF). ***, **, and * indicate statistical significance at the $1 \%, 5 \%$, and $10 \%$ levels, respectively.

\begin{tabular}{lcccc}
\hline & $\mathbf{( 1 )}$ & $\mathbf{( 2 )}$ & $\mathbf{( 3 )}$ & $\mathbf{( 4 )}$ \\
\hline Connection & $0.472^{* *}$ & & $0.432^{* *}$ & \\
& $(0.016)$ & & $(0.021)$ & \\
PC Index & & $0.185^{* *}$ & & $0.188^{* *}$ \\
& & $(0.026)$ & & $(0.018)$ \\
Gov Index & $0.125^{*}$ & $0.121^{*}$ & $0.144^{* *}$ & $0.142^{*}$ \\
& $(0.067)$ & $(0.075)$ & $(0.048)$ & $(0.051)$ \\
Constant & 0.946 & 0.942 & -0.508 & -0.457 \\
& $(0.696)$ & $(0.698)$ & $(0.840)$ & $(0.855)$ \\
\hline Firm Characteristics & Yes & Yes & Yes & Yes \\
Industry Fixed Effects & Yes & Yes & Yes & Yes \\
Year Fixed Effects & Yes & Yes & Yes & Yes \\
\hline Observations & 770 & 770 & 576 & 576 \\
Pseudo R & 0.018 & 0.017 & 0.032 & 0.032 \\
Max VIF & 1.61 & 1.61 & 1.56 & 1.56 \\
Mean VIF & 1.27 & 1.27 & 1.24 & 1.24 \\
\hline
\end{tabular}




\section{Table 8: Propensity Score Matching-A Quasi Experiment}

This table reports the result of propensity score matching (PSM) for Chinese acquiring and non-acquiring POEs from 2007 to 2016. We match firms using a nearest neighbor propensity score matching algorithm and an array of firm-specific characteristics (ROA, Leverage, Firm Size, Tobin's q, Tangibility) plus the $P C$ Index in the year before the acquiring POE completes its first cross-border merger. Panel A reports the univariate balanced test results for pairs of treatment and control firms after matching. Panel B reports parameter estimates for the probit model used in estimating the propensity scores of the treated and control groups (where the treatment is a cross-border M\&A). We match firms in the year before completing a cross-border M\&A transaction with non-acquiring POEs. The "Pre-Match" column contains the parameter estimates of the probit model estimated using the sample prior to matching. These estimates are then used to generate the propensity scores for matching acquiring and non-acquiring POEs. The "Post-Match" column contains the parameter estimates of the probit model estimated using the subsample of matched treatment-control pairs after matching. We match firms using a one-to-one nearest neighbor propensity score matching, without replacement. Definitions for all variables are provided in Panel A of Table A1 in the appendix. Industry and Year Fixed Effects are included in both regressions in Panel B. We report coefficient estimates with $p$-values in parentheses below. ***, **, and * indicate statistical significance at the $1 \%, 5 \%$, and $10 \%$ levels, respectively.

\begin{tabular}{lcccc}
\hline Panel A & Control & Treatment & Diff. & p-value \\
\hline PC Index & 0.889 & 0.872 & 0.017 & 0.860 \\
ROA & 0.057 & 0.058 & -0.001 & 0.858 \\
Leverage & 0.374 & 0.374 & 0.000 & 0.983 \\
Firm Size & 21.601 & 21.601 & 0.000 & 0.995 \\
Tobin's q & 2.791 & 2.958 & -0.167 & 0.346 \\
Tangibility & 0.210 & 0.205 & 0.005 & 0.674 \\
\hline
\end{tabular}

\begin{tabular}{lcc}
\hline Panel B & Pre-Match & Post-Match \\
\hline PC Index & $0.067^{* * *}$ & 0.003 \\
& $(0.006)$ & $(0.943)$ \\
ROA & $1.087^{*}$ & -0.104 \\
& $(0.086)$ & $(0.929)$ \\
Leverage & $-0.338^{*}$ & 0.082 \\
& $(0.062)$ & $(0.822)$ \\
Firm Size & $0.197^{* * *}$ & -0.009 \\
& $(0.000)$ & $(0.907)$ \\
Tobin's q & 0.028 & 0.012 \\
& $(0.137)$ & $(0.711)$ \\
Tangibility & 0.167 & -0.017 \\
& $(0.449)$ & $(0.970)$ \\
Constant & $-5.895^{* * *}$ & 0.081 \\
& $(0.000)$ & $(0.574)$ \\
\hline Industry Fixed Effects & Yes & Yes \\
Year Fixed Effects & Yes & Yes \\
\hline Observations & 8,141 & 576 \\
Pseudo R & 0.035 & 0.020 \\
P-value of $\chi^{2}$ & $<0.001$ & 0.967 \\
\hline
\end{tabular}


Table 9: The Effect of Political Influence on Becoming Acquisitive-A Quasi Experiment

This table reports the results of a logit regression analysis for acquiring and non-acquiring Chinese POEs between 2007 and 2016 after a top management turnover. The dependent variable is a dummy variable that equals 1 if the POE completes a cross-border M\&A transaction three years after the top management turnover, and 0 otherwise. Chinese non-acquiring companies are the one-to-one nearest neighbors from Table 8. See equation (3) for details. We report coefficient estimates and $p$-values that are calculated using robust standard errors. Industry and Year Fixed Effects are included in both regressions. In the last two rows, we report the maximum and mean variance inflation factors (VIF). ***, **, and * indicate statistical significance at the $1 \%, 5 \%$, and $10 \%$ levels, respectively.

\begin{tabular}{lc}
\hline & $(\mathbf{1})$ \\
\hline Political Turnover & $1.059^{* *}$ \\
& $(0.029)$ \\
Connection & -0.111 \\
& $(0.552)$ \\
Gov Index & 0.082 \\
& $(0.265)$ \\
Constant & -0.731 \\
& $(0.778)$ \\
\hline Firm Characteristics & Yes \\
Industry Fixed Effects & Yes \\
Year Fixed Effects & Yes \\
\hline Observations & 576 \\
Pseudo R & 0.030 \\
Max VIF & 1.54 \\
Mean VIF & 1.23 \\
\hline
\end{tabular}


Table 10: Announcement Returns of Cross-border M\&A Announcements by Chinese POEs

Panel A of this table reports the cumulative average abnormal returns (CAAR) around the announcement date of a cross-border M\&A transaction by a Chinese POE for the event windows $(-1,1),(0,1),(-2,2)$, and $(-3,3)$. The CAARs are calculated using a one-factor market model (employing the value-weighted Shanghai and Shenzhen Composite Index as the market factor). The estimation period spans from 240 to 21 days before the announcement date (see, Du and Boateng, 2015). t-statistics and $p$-values are calculated using robust standard errors. Panel B shows the average difference in the cumulative abnormal returns for the event window $(-1,1)$ between politically connected and non-connected POEs. ***, **, and $*$ indicate statistical significance at the $1 \%, 5 \%$, and $10 \%$ levels, respectively.

\section{Panel A}

\begin{tabular}{cccc}
\hline Event Window & CAAR & t-statistic & p-value \\
\hline$(-1,1)$ & $0.012^{* * *}$ & 3.760 & 0.000 \\
$(0,1)$ & $0.010^{* * *}$ & 3.560 & 0.000 \\
$(-2,2)$ & $0.016^{* * *}$ & 4.150 & 0.000 \\
$(-3,3)$ & $0.019^{* * *}$ & 3.780 & 0.000 \\
\hline Observations & 226 & & \\
\hline
\end{tabular}

\section{Panel B}

\begin{tabular}{lcc}
\hline All Cross-border M\&A & \multicolumn{2}{c}{ Difference in Means } \\
\hline Connected - Non-Connected & $-0.016^{* *}$ & $(0.014)$ \\
\hline Observations & 226 \\
\hline \multicolumn{2}{l}{ First Cross-border M\&A Only } & \multicolumn{1}{c}{ Difference in Means } \\
\hline Connected - Non-Connected & $-0.019^{* *}$ & $(0.012)$ \\
\hline Observations & 176 & \\
\hline
\end{tabular}




\section{Table 11: Announcement Returns Around Cross-border M\&A Announcements}

This table reports the results for OLS regressions of market reactions (i.e. the stock price returns of acquiring Chinese POEs) in response to cross-border M\&A announcements (see equation (4)). The dependent variable is the CAR (Cumulative Abnormal Return) calculated using a one-factor market model (employing the value-weighted Shanghai and Shenzhen Composite Index as the market factor) over the event window $(-1,1)$. Specification (1) includes Connection and all control variables and specification (2) includes PC Index and all control variables; both models are for all cross-border M\&A announcements. Specifications (1)' and (2)' are based on subsamples of the data and include only the CAR of the first cross-border M\&A announcement for each POE. Therefore, the variable Multi Acquirer is not included in the model. The variable All Stock Deal is also not included, because there was no cross-border M\&A transaction that was financed only with stocks within the subsample for first crossborder M\&A announcement for each POE. Therefore, the variable Multi Acquirer is not included in the model. The variable All Stock Deal is also excluded, because none of the cross-border M\&A transactions within the first-transaction subsamples were financed purely with stocks. All variables are defined in Table A1 in the appendix. We report coefficient estimates with $p$-values in parentheses below. $p$-values are calculated using robust standard errors at the firm level. Industry and Year Fixed Effects are included in all regressions. In the last two rows, we report the maximum and mean variance inflation factors (VIF). $* * *, * *$, and $*$ indicate statistical significance at the $1 \%, 5 \%$, and $10 \%$ levels, respectively.

\begin{tabular}{|c|c|c|c|c|}
\hline & (1) & (2) & $(1)^{\prime}$ & (2)' \\
\hline \multirow[t]{2}{*}{ Connection } & $-0.016 * *$ & & $-0.016^{*}$ & \\
\hline & $(0.017)$ & & $(0.054)$ & \\
\hline \multirow[t]{2}{*}{ PC Index } & & $-0.007 * *$ & & $-0.007 * *$ \\
\hline & & $(0.029)$ & & $(0.045)$ \\
\hline \multirow[t]{2}{*}{ Gov Index } & -0.000 & -0.000 & -0.003 & -0.003 \\
\hline & $(0.892)$ & $(0.973)$ & $(0.335)$ & $(0.352)$ \\
\hline \multirow[t]{2}{*}{ Culture Distance } & 0.000 & 0.000 & 0.000 & 0.000 \\
\hline & $(0.608)$ & $(0.534)$ & $(0.607)$ & $(0.547)$ \\
\hline \multirow[t]{2}{*}{ Hofstede } & -0.000 & -0.000 & 0.001 & 0.001 \\
\hline & $(0.871)$ & $(0.893)$ & $(0.272)$ & $(0.271)$ \\
\hline \multirow[t]{2}{*}{ Multi Acquirer } & 0.006 & 0.006 & - & - \\
\hline & $(0.443)$ & $(0.496)$ & & \\
\hline \multirow[t]{2}{*}{ Deal Size } & 0.001 & 0.001 & 0.001 & 0.001 \\
\hline & $(0.727)$ & $(0.663)$ & $(0.655)$ & $(0.596)$ \\
\hline \multirow[t]{2}{*}{ Public Target } & -0.014 & -0.016 & -0.003 & -0.004 \\
\hline & $(0.230)$ & $(0.145)$ & $(0.817)$ & $(0.741)$ \\
\hline \multirow[t]{2}{*}{ All Cash Deal } & $0.042 * * *$ & $0.046^{* * *}$ & $0.032^{*}$ & $0.036^{* *}$ \\
\hline & $(0.006)$ & $(0.002)$ & $(0.076)$ & $(0.036)$ \\
\hline \multirow[t]{2}{*}{ All Stock Deal } & -0.013 & -0.012 & - & - \\
\hline & $(0.548)$ & $(0.582)$ & & \\
\hline \multirow[t]{2}{*}{ Common Law } & -0.014 & -0.014 & -0.014 & -0.014 \\
\hline & $(0.118)$ & $(0.126)$ & $(0.167)$ & $(0.171)$ \\
\hline \multirow[t]{2}{*}{ Constant } & 0.078 & 0.069 & 0.125 & 0.119 \\
\hline & $(0.388)$ & $(0.439)$ & $(0.228)$ & $(0.242)$ \\
\hline Firm Characteristics & Yes & Yes & Yes & Yes \\
\hline Industry Fixed Effects & Yes & Yes & Yes & Yes \\
\hline Year Fixed Effects & Yes & Yes & Yes & Yes \\
\hline Observations & 226 & 226 & 176 & 176 \\
\hline $\mathrm{R}^{2}$ & 0.183 & 0.182 & 0.222 & 0.226 \\
\hline Max VIF & 2.14 & 2.14 & 2.14 & 2.01 \\
\hline Mean VIF & 1.45 & 1.45 & 1.45 & 1.36 \\
\hline
\end{tabular}


Table 12: The Financial Performance of POEs after Cross-border M\&A

\section{Transactions}

This table shows the effect of political connections on financial performance (as measured by $R O E$ ) and demonstrates how this relationship is affected by a cross-border M\&A within the three years after deal completion. The dependent variable is the return on equity $(R O E)$ of Chinese POEs. See equation (5) for details. We report coefficient estimates with $p$-values in parentheses below. Industry and Year Fixed Effects are included in the regression. In the last two rows, we report the maximum and mean variance inflation factors (VIF). ***,**, and * indicate statistical significance at the $1 \%, 5 \%$, and $10 \%$ levels, respectively.

\begin{tabular}{lc}
\hline & $(\mathbf{1})$ \\
\hline Connection & $0.054^{* * *}$ \\
Post CBMA & $(0.000)$ \\
& $0.075^{* *}$ \\
Post CBMA $\times$ Connection & $(0.031)$ \\
& $-0.198^{* * *}$ \\
Gov Index & $(0.000)$ \\
& -0.005 \\
Multi Acquirer & $(0.340)$ \\
& $0.164^{* * *}$ \\
Constant & $(0.005)$ \\
& $-1.381^{* * *}$ \\
\hline Firm Characteristics & $(0.000)$ \\
Industry Fixed Effects & Yes \\
Year Fixed Effects & Yes \\
\hline Observations & Yes \\
Adjusted R & 9,946 \\
Max VIF & 0.066 \\
Mean VIF & 1.68 \\
\hline
\end{tabular}


APPENDIX 
Table 1: Variable Definitions

Panel A: Independent Variables

\begin{tabular}{|c|c|c|}
\hline Variable & Definition & Source \\
\hline CBMA & $\begin{array}{l}\text { Dummy variable that equals } 1 \text { when a POE is an } \\
\text { acquiring POE and } 0 \text { otherwise. Specifically, the dummy } \\
\text { variable equals } 1 \text { if a given POE conducts a cross-border } \\
\text { M\&A in a given year, and } 0 \text { otherwise. }\end{array}$ & $\begin{array}{l}\text { CSMAR: China Listed Firms' } \\
\text { Merger \& Acquisition, Asset } \\
\text { Restructuring Research Database }\end{array}$ \\
\hline Connection & $\begin{array}{l}\text { Dummy variable that equals } 1 \text { if the chairman or CEO is } \\
\text { currently working or has worked in a central or local } \\
\text { government department, the military, the People's } \\
\text { Congress (PC), the People's Court and Procuratorate, or } \\
\text { the Chinese People's Political Consultative Conference } \\
\text { (CPPCC), and } 0 \text { otherwise. }\end{array}$ & http://www.stockstar.com/ \\
\hline PC Index & $\begin{array}{l}\text { Political connection measure that equals } 3 \text { if the } \\
\text { politically connected chairman or CEO is the head of a } \\
\text { government department or the head or a standing member } \\
\text { of the PC or CPPCC, } 2 \text { if ( } \mathrm{s} \text { )he is a member of the PC or } \\
\text { CPPCC, } 1 \text { if (s)he is an officer of a local government } \\
\text { department or a military officer, and } 0 \text { otherwise. }\end{array}$ & http://www.stockstar.com/ \\
\hline $\begin{array}{l}\mathrm{LBH} \\
\text { Connection }\end{array}$ & $\begin{array}{l}\text { Percentage of ownership for the largest politically- } \\
\text { connected blockholder in a POE, if said ownership is at } \\
\text { least } 10 \% \text {. The blockholder is considered to be politically } \\
\text { connected if (s)he is currently working (or has worked) in } \\
\text { a central or local government department, the military, the } \\
\text { People's Congress (PC), the People's Court and } \\
\text { Procuratorate, or the Chinese People's Political } \\
\text { Consultative Conference (CPPCC). The blockholder is } \\
\text { also considered politically connected if it is a state entity. } \\
\text { In addition, this blockholder cannot be the chairman/CEO } \\
\text { at the same time. Otherwise, the variable is } 0 .\end{array}$ & $\begin{array}{l}\text { http://www.stockstar.com/ } \\
\text { CSMAR: China Listed Firms' } \\
\text { Corporate Governance Research } \\
\text { Database }\end{array}$ \\
\hline $\begin{array}{l}\text { Multi BH } \\
\text { Connections }\end{array}$ & $\begin{array}{l}\text { Dummy variable that equals } 1 \text { if more than one } \\
\text { blockholder is politically connected and } 0 \text { otherwise. In } \\
\text { addition, these blockholders cannot be the chairman/CEO } \\
\text { at the same time. }\end{array}$ & $\begin{array}{l}\text { http://www.stockstar.com/ } \\
\text { CSMAR: China Listed Firms' } \\
\text { Corporate Governance Research } \\
\text { Database }\end{array}$ \\
\hline ROA & Net income over the value of total assets. & $\begin{array}{l}\text { CSMAR: China Stock Market } \\
\text { Financial Statements Database }\end{array}$ \\
\hline ROE & $\begin{array}{l}\text { Net income over the book value of total shareholders' } \\
\text { equity. }\end{array}$ & $\begin{array}{l}\text { CSMAR: China Stock Market } \\
\text { Financial Statements Database }\end{array}$ \\
\hline Leverage & $\begin{array}{l}\text { Book value of total liabilities over the book value of total } \\
\text { assets. }\end{array}$ & $\begin{array}{l}\text { CSMAR: China Stock Market } \\
\text { Financial Statements Database }\end{array}$ \\
\hline Firm Size & Logarithm of the book value of total assets. & $\begin{array}{l}\text { CSMAR: China Stock Market } \\
\text { Financial Statements Database }\end{array}$ \\
\hline Tobin's q & $\begin{array}{l}\text { Sum of the market value of equity and the book value of } \\
\text { debt over the sum of the book value of equity and the } \\
\text { book value of debt. }\end{array}$ & $\begin{array}{l}\text { CSMAR: China Stock Market } \\
\text { Financial Statements Database }\end{array}$ \\
\hline Tangibility & Net fixed assets over the value of total assets. & $\begin{array}{l}\text { CSMAR: China Stock Market } \\
\text { Financial Statements Database }\end{array}$ \\
\hline
\end{tabular}

(continued) 
Table A1: Variable Definitions-continued

\begin{tabular}{|c|c|c|}
\hline Variable & Definition & Source \\
\hline CAAR & $\begin{array}{l}\text { Cumulative Average Abnormal Return calculated using a } \\
\text { one-factor market model (the return on the value- } \\
\text { weighted Shanghai and Shenzhen Composite Index) over } \\
\text { the event window }(-1,1)\end{array}$ & $\begin{array}{l}\text { CSMAR: China Stock Market } \\
\text { Trading Database }\end{array}$ \\
\hline CAR & $\begin{array}{l}\text { Cumulative Abnormal Return calculated using a one- } \\
\text { factor market model (the return on the value-weighted } \\
\text { Shanghai and Shenzhen Composite Index) over the event } \\
\text { window }(-1,1)\end{array}$ & $\begin{array}{l}\text { CSMAR: China Stock Market } \\
\text { Trading Database }\end{array}$ \\
\hline Hofstede & $\begin{array}{l}\text { Bilateral difference in the sum of Hofstede's six- } \\
\text { dimensional national culture index between China and the } \\
\text { country in which the target firm is located. }\end{array}$ & $\begin{array}{l}\text { Hofstede (1980) } \\
\text { https://geert-hofstede.com/ }\end{array}$ \\
\hline $\begin{array}{l}\text { Culture } \\
\text { Distance }\end{array}$ & $\begin{array}{l}\text { CEPII's distances measure: Bilateral distances weighted } \\
\text { by the share of the city's population in the overall } \\
\text { country's population between the biggest city of China } \\
\text { and the biggest city of the country in which the target } \\
\text { firm is located }\end{array}$ & $\begin{array}{l}\text { Mayer and Zignago (2011) } \\
\text { http://www.cepii.fr/CEPII/en/bdd_m } \\
\text { odele/presentation.asp?id=6 }\end{array}$ \\
\hline $\begin{array}{l}\text { Multi } \\
\text { Acquirer }\end{array}$ & $\begin{array}{l}\text { Dummy variable that equals } 1 \text { if an acquiring POE } \\
\text { completes more than one cross-border } M \& A \text {, and } 0 \\
\text { otherwise. }\end{array}$ & $\begin{array}{l}\text { CSMAR: China Listed Firms' } \\
\text { Merger \& Acquisition, Asset } \\
\text { Restructuring Research Database }\end{array}$ \\
\hline Deal Size & Logarithm of the appraised value of the target firm. & $\begin{array}{l}\text { CSMAR: China Listed Firms' } \\
\text { Merger \& Acquisition, Asset } \\
\text { Restructuring Research Database }\end{array}$ \\
\hline Public Target & $\begin{array}{l}\text { Dummy variable that equals } 1 \text { if the target firm is a public } \\
\text { listed company, and } 0 \text { otherwise. }\end{array}$ & $\begin{array}{l}\text { CSMAR: China Listed Firms' } \\
\text { Merger \& Acquisition, Asset } \\
\text { Restructuring Research Database }\end{array}$ \\
\hline All Cash Deal & $\begin{array}{l}\text { Dummy variable that equals } 1 \text { if the cross-border M\&A is } \\
\text { paid with cash only, and } 0 \text { otherwise. }\end{array}$ & $\begin{array}{l}\text { CSMAR: China Listed Firms' } \\
\text { Merger \& Acquisition, Asset } \\
\text { Restructuring Research Database }\end{array}$ \\
\hline $\begin{array}{l}\text { All Stock } \\
\text { Deal }\end{array}$ & $\begin{array}{l}\text { Dummy variable that equals } 1 \text { if the cross-border M\&A is } \\
\text { paid with stock only, and } 0 \text { otherwise. }\end{array}$ & $\begin{array}{l}\text { CSMAR: China Listed Firms' } \\
\text { Merger \& Acquisition, Asset } \\
\text { Restructuring Research Database }\end{array}$ \\
\hline $\begin{array}{l}\text { Common } \\
\text { Law }\end{array}$ & $\begin{array}{l}\text { Dummy variable that equals } 1 \text { if the target firm is located } \\
\text { in a country that applies common law, and } 0 \text { otherwise. }\end{array}$ & $\begin{array}{l}\text { CSMAR: China Listed Firms' } \\
\text { Merger \& Acquisition, Asset } \\
\text { Restructuring Research Database }\end{array}$ \\
\hline
\end{tabular}




\section{Table A1: Variable Definitions-continued}

\section{Panel B: The Corporate Governance Index}

The Corporate Governance Index is constructed as in Schweizer, Walker, and Zhang (2016) and reflects the sum of the nine governance mechanisms described below.

\begin{tabular}{|c|c|c|}
\hline \multicolumn{3}{|c|}{ Gov Index $_{i, t}=\sum_{j=1}^{9}$ Governance $_{\text {Mechanism }_{j}}$} \\
\hline $\begin{array}{l}\text { Governance } \\
\text { Mechanism }\end{array}$ & Definition & Measurement and Supporting Literature \\
\hline Chairman age & Age of the company's chairman & $\begin{array}{l}\text { Equals } 1 \text { if the age of the chairman of firm } i \text { in fiscal } \\
\text { year } t \text { is less than the mean value of the sample in } \\
\text { fiscal year } t \text {, and } 0 \text { otherwise (Waelchli and Zeller, } \\
\text { 2013; Jiang and Kim, 2015). }{ }^{15}\end{array}$ \\
\hline Chairman tenure & $\begin{array}{l}\text { Number of years the company's } \\
\text { chairman has been in office }\end{array}$ & $\begin{array}{l}\text { Equals } 1 \text { if the tenure of the chairman of firm } i \text { in } \\
\text { fiscal year } t \text { is less than the mean value of the sample } \\
\text { in fiscal year } t \text {, and } 0 \text { otherwise (Berger, Ofek, and } \\
\text { Yermack, 1997; Jiang and Kim, 2015). }\end{array}$ \\
\hline Board size & $\begin{array}{l}\text { Number of directors on the board } \\
\text { of directors }\end{array}$ & $\begin{array}{l}\text { Equals } 1 \text { if the board size of firm } i \text { in fiscal year } t \text { is } \\
\text { less than the mean value of the sample in fiscal year } \\
t \text {, and } 0 \text { otherwise (Yermack, 1996; Conyon and } \\
\text { Peck, 1998; Core, Holthausen, and Larcker, 1999). }\end{array}$ \\
\hline Board independence & $\begin{array}{l}\text { Number of independent directors } \\
\text { on the board of directors }\end{array}$ & $\begin{array}{l}\text { Equals } 1 \text { if the number of independent directors on } \\
\text { the board of firm } i \text { in fiscal year } t \text { is greater than the } \\
\text { mean value of the sample in fiscal year t, and } 0 \\
\text { otherwise (Agrawal and Knoeber, 1996; Kim, } \\
\text { Kitsabunnarat-Chatjuthamard, and Nofsinger, 2007). }\end{array}$ \\
\hline Board meeting & $\begin{array}{l}\text { Number of annual meetings of } \\
\text { the board of directors }\end{array}$ & $\begin{array}{l}\text { Equals } 1 \text { if the number of annual meetings of the } \\
\text { board of directors of firm } i \text { in fiscal year } t \text { is less than } \\
\text { the mean value of the sample in fiscal year } t \text {, and } 0 \\
\text { otherwise (Vafeas, 1999; Yi, Yu, and Jiang, 2011). }\end{array}$ \\
\hline $\begin{array}{l}\text { Supervisory board } \\
\text { size }\end{array}$ & $\begin{array}{l}\text { Number of supervisors on the } \\
\text { supervisory board }\end{array}$ & $\begin{array}{l}\text { Equals } 1 \text { if the number of supervisors on the } \\
\text { supervisory board of firm } i \text { in fiscal year } t \text { is greater } \\
\text { than the mean value of the sample in fiscal year } t \text {, } \\
\text { and } 0 \text { otherwise (Firth et al., 2007; Ding et al., 2010; } \\
\text { Jia et al., 2009). }\end{array}$ \\
\hline $\begin{array}{l}\text { Ownership } \\
\text { concentration }\end{array}$ & $\begin{array}{l}\text { Percentage of shares held by the } \\
\text { company's largest shareholder }\end{array}$ & $\begin{array}{l}\text { Equals } 1 \text { if the percentage of shares held by the } \\
\text { company's largest shareholder of firm } i \text { in fiscal year } \\
t \text { is greater than the mean value of the sample in } \\
\text { fiscal year } t \text {, and } 0 \text { otherwise (Stiglitz, 1985; Rediker } \\
\text { and Seth, 1995; Voulgaris, Stathopoulos, and } \\
\text { Walker, 2010; Huang et al., 2011). }\end{array}$ \\
\hline Foreign auditor & Hiring of a foreign auditor & $\begin{array}{l}\text { Equals } 1 \text { if firm } i \text { hires a foreign auditor in fiscal year } \\
t \text {, and } 0 \text { otherwise (Gao and Kling, 2008; Peng, Wei, } \\
\text { and Yang, 2011). }\end{array}$ \\
\hline State shares & $\begin{array}{l}\text { State shares account for at least } \\
5 \% \text { of the firm's total shares }\end{array}$ & $\begin{array}{l}\text { Equals } 0 \text { if the state holds more than } 5 \% \text { of the } \\
\text { shares in firm } i \text { in fiscal year } t \text {, and } 1 \text { otherwise } \\
\text { (Bloom et al., 2012; Jiang, Huang, and Kim, 2013). }\end{array}$ \\
\hline
\end{tabular}

\footnotetext{
${ }^{15}$ As Jiang and Kim (2015, pp 209) point out, using chairman age and tenure for constructing the corporate governance index for Chinese companies is appropriate because "the actual person who is actively in charge of the business is not the CEO. It is the board chairperson who actively controls and runs the firm. In China, this is common knowledge. However, based on the academic literature, it seems that many scholars are unaware of this."
} 


\section{Table A2: The Effect of Blockholders' Political Connections on Becoming}

Acquisitive

This table reports the results of a panel logit regression analysis (columns (1) and (2)) and a postmatching cross-sectional logit regression analysis (columns (3) and (4)) for all cross-border acquiring and non-acquiring POEs between 2007 and 2016. Columns (5) and (6) repeat the post-matching cross sectional analyses, but only consider the first cross-border deal for each acquisitive POE. Acquiring POEs are defined as those with at least one cross-border M\&A transaction within the sample period. The dependent variable is a dummy variable that equals 1 if the POE completes a cross-border M\&A deal in a given year, and 0 otherwise. See equation (1) for details. To measure the political connections of blockholders, we employ the variables LBH Connection (the percentage ownership of the largest politically-connected blockholder) and Multi BH Connections (a dummy variable indicating whether a firm has multiple politically-connected blockholders). We report coefficient estimates with $p$-values in parentheses below. Industry and Year Fixed Effects are included in all regressions. In the last two rows, we report the maximum and mean variance inflation factors (VIF). ***,**, and * indicate statistical significance at the $1 \%, 5 \%$, and $10 \%$ levels, respectively.

\begin{tabular}{lcccccc}
\hline & $\mathbf{( 1 )}$ & $\mathbf{( 2 )}$ & $\mathbf{( 3 )}$ & $\mathbf{( 4 )}$ & $\mathbf{( 5 )}$ & $\mathbf{( 6 )}$ \\
\hline Connection & $1.331^{* * *}$ & & $0.466^{* *}$ & & $0.395^{* *}$ & \\
& $(0.000)$ & & $(0.018)$ & & $(0.037)$ & \\
PC Index & & $0.488^{* * *}$ & & $0.179^{* *}$ & & $0.173^{* *}$ \\
& & $(0.000)$ & & $(0.031)$ & & $(0.031)$ \\
LBH Connection & $-4.724^{* *}$ & $-4.555^{* *}$ & -0.059 & 0.011 & -1.104 & -1.121 \\
& $(0.014)$ & $(0.015)$ & $(0.964)$ & $(0.993)$ & $(0.319)$ & $(0.315)$ \\
Multi BH Connections & -9.735 & -8.974 & -2.036 & -2.017 & -1.229 & -1.197 \\
& $(0.986)$ & $(0.982)$ & $(0.103)$ & $(0.103)$ & $(0.306)$ & $(0.317)$ \\
Gov Index & 0.030 & 0.028 & $0.133^{*}$ & $0.129 *$ & $0.149^{* *}$ & $0.146^{* *}$ \\
& $(0.605)$ & $(0.627)$ & $(0.054)$ & $(0.060)$ & $(0.042)$ & $(0.044)$ \\
Constant & & & 0.602 & 0.577 & -0.896 & -0.846 \\
& & & $(0.804)$ & $(0.812)$ & $(0.725)$ & $(0.740)$ \\
\hline Firm Characteristics & Yes & Yes & Yes & Yes & Yes & Yes \\
Industry Fixed Effects & Yes & Yes & Yes & Yes & Yes & Yes \\
Year Fixed Effects & Yes & Yes & Yes & Yes & Yes & Yes \\
\hline Observations & 9,946 & 9,946 & 770 & 770 & 576 & 576 \\
Maximum VIF & 1.48 & 1.48 & 1.63 & 1.63 & 1.59 & 1.59 \\
Mean VIF & 1.20 & 1.20 & 1.25 & 1.25 & 1.24 & 1.23 \\
\hline
\end{tabular}




\section{Table A3: The Effect of Blockholders' Political Influence on Becoming Acquisitive-A Quasi Experiment}

This table reports the results of a logit regression analysis for acquiring and non- acquiring Chinese POEs between 2007 and 2016 after the change in the political connections of the blockholders within the five years before the firm's first cross-border M\&A. The dependent variable is a dummy variable that equals 1 if the POE completes a cross-border M\&A transaction, and 0 otherwise. Non-acquiring companies are identified via a one-to-one nearest neighbor propensity score matching algorithm. To measure the political connections of blockholders, we employ the variables LBH Connection (the percentage of the largest politically-connected blockholder) and Multi BH Connections (a dummy variable indicating whether a firm has multiple politically-connected blockholders). We report coefficient estimates with $p$ values in parentheses below. $p$-values are calculated using robust standard errors. Industry and Year Fixed Effects are included in all regressions. In the last two rows, we report the maximum and mean variance inflation factors (VIF). ***, **, and * indicate statistical significance at the $1 \%, 5 \%$, and $10 \%$ levels, respectively.

\begin{tabular}{lc}
\hline & $(\mathbf{1})$ \\
\hline PBH Turnover & -0.230 \\
LBH Connection & $(0.839)$ \\
& -1.167 \\
Multi BH Connections & $(0.327)$ \\
& -1.325 \\
Gov Index & $(0.269)$ \\
& $0.148^{* *}$ \\
Constant & $(0.043)$ \\
& -0.904 \\
Firm Characteristics & $(0.724)$ \\
Industry Fixed Effects & Yes \\
Year Fixed Effects & Yes \\
\hline Maximum VIF & Yes \\
Mean VIF & 1.59 \\
\hline Observations & 1.27 \\
Pseudo R & 576 \\
\hline
\end{tabular}




\section{Table A4: Poisson Regression Analysis}

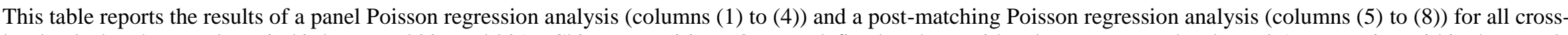

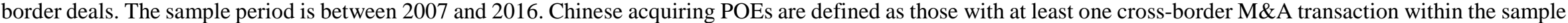

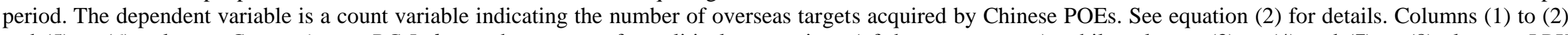

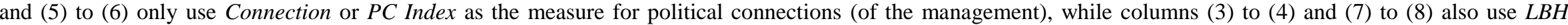

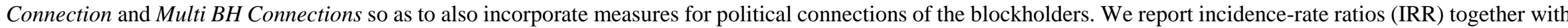

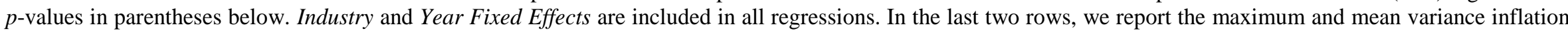
factors (VIF). ***, **, and * indicate statistical significance at the $1 \%, 5 \%$, and $10 \%$ levels, respectively.

\begin{tabular}{|c|c|c|c|c|c|c|c|c|}
\hline & (1) & (2) & (3) & (4) & (5) & (6) & (7) & (8) \\
\hline Connection & $\begin{array}{c}1.511 * * * \\
(0.002)\end{array}$ & & $\begin{array}{c}1.156^{* * *} * \\
(0.002)\end{array}$ & & $\begin{array}{c}1.301 * * * \\
(0.006)\end{array}$ & & $\begin{array}{c}1.305 * * * \\
(0.006)\end{array}$ & \\
\hline PC Index & & $\begin{array}{c}1.148 * * \\
(0.013)\end{array}$ & & $\begin{array}{c}1.147 * * \\
(0.014)\end{array}$ & & $\begin{array}{c}1.115^{* * * *} \\
(0.008)\end{array}$ & & $\begin{array}{c}1.115^{* * * *} \\
(0.008)\end{array}$ \\
\hline Gov Index & $\begin{array}{c}1.026 \\
(0.542)\end{array}$ & $\begin{array}{c}1.024 \\
(0.567)\end{array}$ & $\begin{array}{c}1.025 \\
(0.548)\end{array}$ & $\begin{array}{c}1.024 \\
(0.573)\end{array}$ & $\begin{array}{c}0.993 \\
(0.862)\end{array}$ & $\begin{array}{c}0.993 \\
(0.858)\end{array}$ & $\begin{array}{c}0.994 \\
(0.877)\end{array}$ & $\begin{array}{c}0.994 \\
(0.873)\end{array}$ \\
\hline LBH Connection & & & $\begin{array}{c}0.318 \\
(0.135)\end{array}$ & $\begin{array}{c}0.341 \\
(0.159)\end{array}$ & & & $\begin{array}{c}0.785 \\
(0.685)\end{array}$ & $\begin{array}{c}0.832 \\
(0.757)\end{array}$ \\
\hline Multi BH Connections & & & $\begin{array}{c}0.302 \\
(0.284)\end{array}$ & $\begin{array}{c}0.300 \\
(0.282)\end{array}$ & & & $\begin{array}{c}0.325 \\
(0.275)\end{array}$ & $\begin{array}{c}0.326 \\
(0.277)\end{array}$ \\
\hline Constant & & & & & $\begin{array}{c}0.000 * * * \\
(0.000)\end{array}$ & $\begin{array}{c}0.000 * * * \\
(0.000)\end{array}$ & $\begin{array}{c}0.000 * * * \\
(0.000)\end{array}$ & $\begin{array}{c}0.000 * * * \\
(0.000)\end{array}$ \\
\hline Firm Characteristics & Yes & Yes & Yes & Yes & Yes & Yes & Yes & Yes \\
\hline Industry Fixed Effects & Yes & Yes & Yes & Yes & Yes & Yes & Yes & Yes \\
\hline Year Fixed Effects & Yes & Yes & Yes & Yes & Yes & Yes & Yes & Yes \\
\hline Observations & 9,946 & 9,946 & 9,946 & 9,946 & 770 & 770 & 770 & 770 \\
\hline Max VIF & 1.46 & 1.46 & 1.48 & 1.48 & 1.61 & 1.61 & 1.63 & 1.63 \\
\hline Mean VIF & 1.22 & 1.22 & 1.20 & 1.20 & 1.27 & 1.27 & 1.25 & 1.25 \\
\hline
\end{tabular}

